\title{
When risk and return are not enough: the role of loss aversion in private investors' choice of mutual fund fee structures
}

\author{
Christian Ehm* Martin Weber**
}

April 17, 2013

\begin{abstract}
We analyze why investors chose funds with performance fees even if expected fees are higher than in a fund with a pure management fee. These fees are meant to influence performance positively but they can also lead to a higher fund risk. The expected higher performance cannot fully account for the height of the performance fees chosen in our survey study. Controlling for various other explanations, we find that loss aversion is a main driver for the propensity to chose a performance fee fund.
\end{abstract}

Keywords: Hedge funds, mutual funds, fees, performance fees, incentive fees, loss aversion

JEL classification: G11, G23

\footnotetext{
*University of Mannheim, Chair of Banking, contact: ehm@bank.bwl.uni-mannheim.de ** University of Mannheim, Chair of Banking, contact: weber@bank.bwl.uni-mannheim.de We thank Alexandra Niessen-Ruenzi as well as all seminar participants at the 3rd Annual Boulder Summer Conference on Financial Decision Making and at the University of Mannheim for valuable suggestions which helped to improve the paper.
} 


\section{Introduction}

Fund fees are one of the most important criteria for choosing a fund (Sirri and Tufano, 1998; West and Leonard-Chambers, 2006). Barber et al. (2005) find that investors increasingly take fees into account. Given the role of fees, it is important to understand why investors choose certain fee structures. This choice is a non-trivial task as various fee structures exist that can influence fund performance differently. One important distinction is the difference between a management fee and a performance fee. While a management fee is typically a percentage of the funds assets under management, a performance fee is typically a percentage of the funds gains. Performance fees can be both asymmetric (meaning that the investment company only collects part of the gains) and symmetric (meaning that the investment company also refunds part of the losses). Both U.S. and European hedge funds typically use asymmetric performance fees. Fee structures for mutual funds however are not identical in the U.S. and in Europe. Mutual funds with asymmetric performance fees are common in Europe. In Germany for example, more than one third of the assets under management in open-end funds are in funds with asymmetric performance fees. ${ }^{1}$ In the U.S., only symmetric performance fees are allowed for mutual funds. Golec and Starks (2004) mention that more and more mutual funds use these symmetric performance fees. U.S. hedge funds however widely use asymmetric performance fees. Performance fees in general are widely used; we focus on asymmetric ones. This paper shows which factors contribute to the choice of a fund with a performance fee. We document that loss aversion (Kahneman and Tversky, 1979, 1984) is a main driver for this choice.

Various possible reasons for the preference for a performance fee fund exist. One rea-

\footnotetext{
${ }^{1}$ Own calculation based on Morningstar direct. Starting in July 2013, performance fees of new funds in Germany are regulated to a stronger extent. Only two forms are allowed: either a fee with a benchmark index or a high-water mark construction. The fee we use in our study is comparable to a high-water mark construction in the first year as it is paid on all positive returns in the first year of a fund's existence.
} 
son is the expectation of a higher performance. Agency theory posits that a principal (such as a mutual fund investor) should incentivize an agent (such as the investment company) to achieve a higher performance with payments linked to the agent's performance (e.g. Berhold, 1971; Jensen and Meckling, 1976; Elton et al., 2003). Agency theory also provides a reason against performance fees; performance fees may induce extensive risk taking. Grinblatt and Titman (1989) and Carpenter (2000) show that asymmetric performance fees lead to extensive risk taking. Starks (1987) models symmetric and asymmetric performance fees. She finds that a manager with symmetric performance fees will chose the optimal risk from the investor's perspective while a manager with asymmetric fees will tend to excessive risk taking. Das and Sundaram (2002) find the exact opposite. They compare symmetric and asymmetric performance fees and show that asymmetric fees are better for investors. Li and Tiwari (2009) partly confirm this finding. In their model, asymmetric fees are better suited to incentivize managers if the fee depends on a benchmark and if this benchmark closely tracks the manager's investment style. From the theoretical perspective, the incentivization resulting from both symmetric and asymmetric performance fees can lead to better performance and to extensive risk-taking.

The empirical literature has confirmed some of these theoretical findings. Fees have an important influence on fund performance; Carhart (1997) shows that fees have a negative impact on performance. Fees in general can lead to manager incentives that are not aligned with the investors' ones: Chevalier and Ellison (1997) and Brown et al. (1996) show that funds increase their volatility in order to benefit from fees. This also implies that the fund managers' behavior depends on the compensation scheme of the fund itself; investors can expect the funds compensation scheme to affect the choice of assets and thus also the performance of the fund. Massa and Patgiri (2009) show that performance fees can lead to a positive alpha but at the cost of a higher volatility and a 
lower probability for the fund to survive. Golec and Starks (2004) use the prohibition of asymmetric performance fees in the U.S. to analyze the impact of these fees. They find that the prohibition made funds increase their risk to a lesser extent than comparable funds. This implies that asymmetric fees can lead to an increase in risk. Evidence for symmetric performance fees goes in the opposite direction. Elton et al. (2003) analyze U.S. mutual funds with symmetric performance fees. These funds appear to generate an alpha due to stock picking ability and due to lower costs. Empirically, funds with symmetric performance fees appear to be more beneficial for investors. From these previous findings, we derive our first hypotheses. As the incentivization from performance fees can lead to both positive and negative consequences, the average investor could perceive incentivization effects to be neutral.

- Investors who perceive a better performance to be the dominating effect of a performance fee prefer performance fee funds.

- Investors who perceive an increase in risk to be the dominating effect of a performance fee prefer funds with a pure management fee.

Apart from these rational preferences for or against a performance fee, non-rational reasons could exist. Such a reason is fairness. Baker et al. (1988) hypothesize that fairness is an aspect that complements incentives. Carroll (1989) considers fairness as an important aspect of performance fees; he argues that fairness should be a part of the compensation scheme such that managers benefit from a good performance. Another possible reason for a performance fee may be the loss aversion of an investor. A performance fee is paid in case of positive returns; in turn the fee in case of negative returns is lower. Consequently a performance fee allows an investor to reduce a loss by reducing his gains. As losses are more heavily weighted than gains of the same size (cf. Kahneman and Tversky, 1979; Tversky and Kahneman, 1992), a loss-averse investor should prefer a performance fee over a management fee. The investor can transfer a fee 
from a negative state (where it hurts him more to pay it) to a positive state (where it hurts him less). A similar argument has been investigated by Zamir and Ritov (2010) for the choice of attorneys' fees: Clients who chose a fee that depends on the outcome of the trial (comparable to a performance fee for a fund) are ready to accept a fee with twice to three times the expected amount of a fee that does not depend on the outcome of the trial (comparable to a management fee). Attorneys' clients prefer to give up a larger part of a good outcome if their payment is reduced for bad outcomes. Fairness and loss aversion complete our hypotheses.

- Investors, who feel treated unfairly if they pay a fee in case of negative returns, prefer a pure management fee.

- Investors, who want the fund (manager) to be treated fairly, prefer a performance fee as the fund (manager) benefits more from good outcomes.

- Investors with a higher loss aversion prefer performance fee funds as these allow them to smooth their gains and losses.

We analyze investors' fee preferences with two survey studies. The first one was filled in by 325 participants recruited from the German general population. First, subjects choose between two different hypothetical funds. These are identical except for their fee structures. One fund has a pure management fee (that is calculated as a percentage of the fund's asset at the end of each year) while the other fund has an asymmetric performance fee (that is calculated as a percentage of the fund's gains if there is a positive performance). As our paper is -to the best of our knowledge- the first one to investigate preferences for performance fees, we use a simplified design to gather some insights on this subjects. A one-year investment horizon and a pure performance fee fund (i.e. a fund without any fixed fee whatsoever) is used to make the fees easy to calculate and easy to compare. The one-year horizon avoids effects from previous returns which are common 
in a high-water mark construction. This also allows to circumvent the explanation of the high-water mark construct which may be too complicated for some subjects. The fact that no fixed fee is paid for the performance fee fund reduces our subjects decision to a choice between two simple different fee-types. Both the performance fee fund and the management fee fund invest in securities listed in the Euro Stoxx 50 and try to outperform the Euro Stoxx 50. In order to avoid interference on the hypothesized effects by the past performance of the two funds, they are described as being about to enter the market and not having a performance history. This is important as past performance is one of the main drivers of investors' fund choice (Sirri and Tufano, 1998). The focus on past performance remains when different fees are added to explain fund choice. Choi et al. (2010) find that fees are not sufficiently taken into account and that past performance remains the main driver of fund choice. Neither is this focus on past performance mitigated by mandatory cost information (Pontari et al., 2009) nor by simplified information in form of summary prospectuses (Beshears et al., 2010; Kozup et al., 2008). Instead of a performance history of the funds, the history of the benchmark index is given which can serve as an indication for the funds' performance. Subjects decide upon the maximum performance fee they are willing to pay as compared to a management fee of $1.5 \%$. The same subjects are then presented with a second choice where the maximum performance fee for two different share classes is elicited. The only difference to the two-fund case is that both share classes have identical returns; the fee choice does not influence the incentives of the fund (manager). Subjects are told that both share classes have the same return before fees and that they only differ in fee structure. The past (average and conditional) returns of the share classes and the respective probabilities are given. They equal the numbers for the Euro Stoxx 50 from the decisions for the two different funds. In this case, the rational reasons should not apply such that the focus is on fairness and loss aversion. After this decision, possible 
reasons and control variables are elicited via text questions.

The second study was filled in by 260 participants from the German general population. Subjects were assigned to one of three conditions. In the first condition, they had to decide upon the maximum performance fee and they were asked text questions afterwards (similar to the first study). In the second condition, subjects were asked about possible reasons before they had to decide upon the maximum performance fee. In the third condition, subjects were asked to choose the maximum management fee they are willing to pay as opposed to a fixed performance fee. Afterwards they were asked text questions. The same funds are used in all three conditions. The two funds used are identical to the two funds used in the first study except for the fact that the Euro Stoxx 50 history has another annual return (due to the timing of the second study).

Due to the simplified design, subjects could calculate which fund is cheaper in terms of expected fees such that they could always choose the cheaper fund. Subjects in our sample choose a higher performance fee than such a purely fee minimizing investor would do $(17.4 \%$ on average instead of $10 \%$ in the first study, $15.5 \%$ instead of $10 \%$ in the second study). For both studies, regression analyses indicate that this can be explained with a belief in higher return or lower risk of the performance fee fund and with loss aversion of the investors who choose performance fees. This effect is robust to the inclusion of control variables like gender, age, financial literacy, income, and education. Furthermore, we find that investors seem to rely mainly on economic factors (return, risk, personal well-being) instead of soft factors (fairness towards the fund manager). When text questions are asked first, the average chosen performance fee is reduced to $12.4 \%$ which is closer to a purely fee minimizing investor's choice of $10 \%$ but still above it. The factors influencing this decision remain the same. When subjects decide upon the maximum management fee they are willing to pay, their reasons change with the different focus. In this case, investors are seeking fairness. A belief in higher returns 
of the performance fee fund and loss aversion remain significant predictors. Subjects choose a lower management fee if they fear to pay too much in case of losses.

Evidence on fee choice from previous surveys is limited. Most papers focus on fees in general and do not test different fee structures. Wilcox (2003) uses conjoint analyses to identify investors preferences. He finds that investors with higher financial knowledge and higher wealth consider fees to a lesser extent. Capon et al. (1996) analyze decision criteria with Likert scales. One quarter of their subjects attribute a high importance to management fees. Müller and Weber (2010) find a positive relation between financial literacy and a preference for low-cost funds. To the best of our knowledge, our paper is the first one to directly analyze explanations for different fee structures.

The remainder of this paper proceeds as follows. Section 2 describes the design of our studies and the resulting data, section 3 describes our results, and section 4 concludes.

\section{Data And Data Collection}

Participants for both studies were recruited from a list of previous study participants who agreed to be contacted again for further studies. The list of previous participants resulted from the studies of Müller and Weber (2010), Kaufmann et al. (2013) and Ehm et al. (2013), which used e-mail distribution list and newspaper articles to recruit their subjects. The study which was closest to our survey was conducted over a year before our surveys such that effects from the participation in these studies can be excluded. Half of the e-mail-addresses on the list were randomly selected for an e-mail with a link to Study I of this paper. The remaining e-mail-addresses were used for Study II. In the invitational e-mail, potential participants were told that they can participate in a survey on mutual funds; the focus on fund fees was not explicitly stated. 325 participants followed the link to the first study and completed it; 260 participants followed the link to the second study and completed it. 


\section{Study I}

Study I consists of three different investment decisions followed by text questions that serve to explain their choices. The study uses a within-subjects design where all participants make all three decisions.

- In the first case, they decide upon the maximum performance fee for a fund with a pure management fee fund as an alternative. Both funds are independent from each other, thus they can have different subsequent returns.

- In the second case, they decide upon the maximum performance fee for one of two share classes of the same fund where both classes have the exact same development. Performance, risk, and fund incentives are the same for both share classes in this case such that these reasons should not play a role for the decision between the different fees.

- In the third case, they decide again between two share classes. This case is used for robustness checks as the share classes have a performance history that is different from the second case.

The exact decision context is as follows.

After a reception screen, participants are presented with the first of three investment decisions where they are asked to invest an hypothetical amount of $€ 10,000$ in either a performance fee fund or in a management fee fund. They are given the following information on the two funds. Both the management fee fund and the performance fee fund invest in securities listed in the Euro Stoxx 50 and try to outperform the Euro Stoxx 50. Both are about to enter the market and have no prior performance history. Subjects cannot rely on past performance of the funds as investors have been shown to do (cf. e.g. Sirri and Tufano, 1998). This allows to focus on fees as they are not interfering with past performance as they have been shown to do (cf. Choi et al., 2010). Subjects receive 
information about the Euro Stoxx 50 instead, which can serve as an indication for the funds' performance and for the funds' fees. Subjects are told the average return of the Euro Stoxx 50 (8.5\% p.a. since introduction), the historical frequencies for positive and negative returns (70\% and $30 \%)$, as well as the average positive $(22.4 \%)$ and negative return $(-23.2 \%)$. Along with this information, they are shown a histogram of the annual Euro Stoxx 50 returns since introduction (see figure 2).

In Study I, the maximum performance fee in all three cases is elicited iteratively. Subjects repeatedly chose between a fixed management fee and a a performance fee. They have to invest the whole investment amount in one fund (or share-class); a split-up is not possible. First, they chose between a $1.5 \%$ management fee (on the net asset value at the end of the year) and a $17.5 \%$ performance fee (on any positive return). If they prefer the performance fee (the management fee), they then chose between the same management fee and a higher (lower) performance fee. With three to four iterations, the indifference point where a subject switches from the performance fee to the management fee is elicited. This point shows which maximum performance fee this subject is ready to pay. The maximum performance fee chosen will be explained with various personal characteristics in the following sections. The maximum and minimum performance fee that can be chosen are $30 \%$ and 5\% respectively. The choice between two funds ("Which fund do you prefer?") as opposed to the direct elicitation of the maximum performance fee ("What is the maximum performance fee you are ready to pay?") has been chosen deliberately. Lichtenstein and Slovic (1971) show that different elicitation methods (choice vs. matching) can lead to a preference reversal. Neither choice nor matching leads to generally true preferences (Carmon and Simonson, 1998). Each method leads to preferences that are true within the respective context. In our context, the elicitation via a choice between two funds is more natural: an investor is more likely to compare different funds and to chose one of them ("choice") than to determine a certain fee structure and 
search for a fund with the chosen fee structure afterwards ("matching").

\section{Insert figure 2 here.}

After the elicitation of the maximum performance fee for two different funds, the maximum performance fee for two different share classes is elicited. The elicitation is again iterative over the same performance fee range as before. The only difference to the two-fund case is that both share classes have identical returns; incentives, managerial risk-taking, and outperformance should be irrelevant in this case. Subjects are told that both share classes have the same return before fees and that they only differ in fee structure. The past (average and conditional) returns of the share classes and the respective probabilities are given. The past performance of the Euro Stoxx 50 is also used as the underlying distribution for the share classes. Consequently, these numbers are the same as in the decisions for the two different funds thus making the two cases comparable. A figure similar to figure 2 is provided. Only the title is different and reads "Past annual returns of the fund". Afterwards, the maximum performance fee for another share class case with a different distribution of returns is elicited. This third decision is used for robustness checks.

For both, the decisions between different funds and the decisions between share classes, subjects were not paid. Camerer and Hogarth (1999) show that incentives are not important in experiments similar to this one (e.g. trading in markets or choosing between risky gambles); consequently the lack of payments should not affect the results. The reason for the lack of a payment is very simple: any possible payment would have been too low. Incentive compatible payments are normally scaled down: if the hypothetical decision context involves thousands of dollars/euros, the payment will nevertheless be below 100 dollars/euros. The part of this down-scaled payment that is due to the fee structure would have been very low. While fees are really important in real-life decisions where they can amount to hundreds of dollars/euros, the impact of the fees in this 
experiment would have been on the cent-level. Other solutions lack practicability as well. A payment based on the chosen fees only would point at the aim of the study. A higher investment amount would make the impact of the fee structure larger but possible payments would become too expensive at the same time.

The elicitation of maximum performance fees is followed by questions on possible reasons for the choice of one fee over the other. The reasons include questions on manager incentives, outperformance, increased managerial risk taking, loss aversion, and fairness. The incentivization of a fund manager is seen as an important aspect in the literature (see e.g. Brown et al., 1996; Massa and Patgiri, 2009); a fund manager that participates in the fund's success is expected to exert higher effort. This can potentially lead to a better performance and to a higher risk taking (cf. Massa and Patgiri, 2009). Investors could also be reluctant to pay a fee when they face a negative return. Tversky and Kahneman (1992) have shown that losses are more heavily weighted than gains of the same size. Following this idea, investors could prefer paying a higher fee in case of positive returns if this allows them to eliminate a fee in case of negative returns. Zamir and Ritov (2010) find the same pattern for the choice of attorneys' compensation schemes; clients try to avoid an additional loss when they face a negative outcome, namely losing in court. Investors may also want the compensation scheme to be fair; on the one hand they might want the manager to benefit from good decisions and on the other hand they might be reluctant to pay for bad decisions. These reasons are measured on 7-point Likert scales with 1 meaning "Strongly disagree" and 7 meaning "Strongly agree". The wording of the questions can be found in table 1. Afterwards, loss aversion and risk aversion are elicited with standard lottery questions. For loss aversion, one indifference between a gain and a loss is needed (Tversky and Kahneman, 1992; Abdellaoui et al., 2008). The loss is fixed to $€ 1,000$ (with a $50 \%$ chance) and the gain that makes subjects indifferent is elicited. For risk aversion, the certainty equivalent for a lottery with a $50 \%$ chance to win $€ 500$ 
and a $50 \%$ chance to win $€ 0$ is elicited.

\section{Insert table 1 here.}

Participants then estimate the level of the Euro Stoxx 50 in one year. This estimate is used to measure optimism. At the time of the estimation, the Euro Stoxx was at around 2,800 points. Subjects who are optimistic about the development of the market should tend to prefer a lower performance fee as the performance fee is more expensive in bull markets. Financial literacy (measured by the advanced questions introduced by van Rooij et al., 2011) and socio-demographics (age, gender, education, and income) are elicited as further control variables.

\section{Study II}

In Study II, further design variations and the robustness of our results are investigated. Instead of the within-subjects design of Study I, a between-subjects design is used. Furthermore, the iterative elicitation of the maximum performance fee is replaced by a more direct elicitation, the belief in a higher or lower performance of the performance fee fund is measured directly, and a text question on signalling as an alternative reason for performance fee funds is added. Participants are randomly assigned to one of three groups:

- In the first group ("Performance fee group"), participants first decide on the maximum performance fee for a fund with a pure management fee fund as an alternative (similar to case 1 in Study I). Afterwards they are asked text questions on the reasons for their choice.

- In the second group ("Text questions group") this order is reversed. Participants first answer the text questions about possible reasons for buying one of the funds, then they decide on the maximum performance fee. 
- In the third group ("Management fee group"), participants first decide on the maximum management fee they are willing to pay. Afterwards they answer the text questions.

After an introduction screen, performance fees and management fees are defined. While participants in Study I could deduce these definitions from the decision context, they are necessary here to establish a level playing field for the different groups. The performance fee is described as a fee that is paid as a percentage of the fund's gains and that is only paid if the fund has positive returns. The management fee is described as a fee that is paid as a percentage of the fund assets irrespective of the fund's performance. After these definitions, both the performance fee group and the management fee group see the same decision context. The text questions group sees this decision context after answering the text questions (described later). The exact decision context is as follows.

Similar to the first decision in Study I, all participants of Study II are asked to invest an hypothetical amount of $€ 10,000$ in either a performance fee fund or in a management fee fund. They are given the following information on the two funds. Both the management fee fund and the performance fee fund invest in securities listed in the Euro Stoxx 50 and try to outperform the Euro Stoxx 50. Both are about to enter the market and have no prior performance history. Again, subjects cannot rely on past performance of the funds. Instead, they receive information about the Euro Stoxx 50 which can serve as an indication for the funds' performance and for the funds' fees. Subjects are told the average return of the Euro Stoxx 50 (6.9\% p.a. since introduction), the historical frequencies for positive and negative returns (65\% and 35\%), as well as the average positive $(22.4 \%)$ and negative return (-20.6\%). These values differ slightly from the ones in Study I as an additional return observation was available for Study II. Along with this information, they are shown a histogram of the annual Euro Stoxx 50 returns since introduction (similar to figure 2). 
After this description, all participants choose between the two funds. They have to invest the whole investment amount in one fund; a split-up is not possible. Again, participants do not receive a payment (cf. discussion on payments for Study I). Participants in the performance fee group and in the text questions group decide on the maximum performance fee they are ready to pay (as opposed to a $1.5 \%$ management fee). The performance fee ranges from $2.5 \%$ to $30 \%$ in steps of 2.5 percentage points. Participants in the management fee group decide on the maximum management fee they are ready to pay (as opposed to a $17.5 \%$ performance fee). The management fee ranges from $0.5 \%$ to $3 \%$ in steps of 0.25 percentage points. While deciding, subjects still see the decision context such that they can make an informed decision. Contrary to Study I, the maximum performance or management fee is not elicited iteratively but subjects see all possible choices at the same time. This avoids an anchor effect resulting from the starting point of an iterative elicitation. At the same time, this design still allows for a choice situation instead of a matching situation which is better suited in this context (cf. Lichtenstein and Slovic, 1971; Carmon and Simonson, 1998). Subjects mark their choice for every combination (e.g. $2.5 \%$ performance fee vs. $1.5 \%$ management fee; $5 \%$ performance fee vs. $1.5 \%$ management fee etc.) and then submit all choices together by clicking on a Go-on-button.

Participants then state their expected performance in percentage points for both funds separately. This question replaces the text question on outperformance from Study I and it allows for a quantification of an estimated outperformance of one of the two funds. Participants in the performance fee group and the management fee group then answer the text questions which have already been answered by participants in the text questions group. The majority of questions from Study I has been used without changes. This includes the questions on manager incentives, increased managerial risk taking, loss aversion, and fairness. The text question on outperformance has been replaced by a 
direct elicitation and a question on signalling has been added. The new question on signalling measures if a participant sees a performance fee as a signal of superior skills of the fund or its advisers (cf. Das and Sundaram, 2002). Like all the text questions, signalling is measured on a 7-point Likert scale with 1 meaning "Strongly disagree" and 7 meaning "Strongly agree". The wording of the questions can be found in table 1. In Study II, loss aversion and risk aversion are not elicited via lottery questions anymore. Given their low explanatory power in Study I, the time-consuming lotteries were eliminated.

In all groups, participants then estimate the level of the Euro Stoxx 50 in one year which is used as a measure for optimism (the Euro Stoxx was at around 2,500 points. Financial literacy (measured by the advanced questions introduced by van Rooij et al., 2011) and socio-demographics (age, gender, education, occupation, and income) are elicited as further control variables.

\section{$\underline{\text { Dataset }}$}

Subjects who participated more than once or who did not answer a minimum number of questions were deleted from both studies. The dataset of Study I consists of the answers of 325 subjects and the dataset of Study II consists of the answers of 260 subjects. Personal characteristics of the participants are shown in table 2. In both studies, education, income, and the high rate of male investors fit the average German investor much better than the average German (cf. Destatis, 2010; Deutsches Aktieninstitut, 2010). Subjects in the studies appear to be more educated and to earn more than the average German. The average financial literacy is very high (9.1 out of 10 in Study I and 9.4 out of 10 in Study II); this should also fit the average investor better than the average German. Perhaps, the average participant should be even better able to judge and to succeed in financial decisions than the average investor. Altogether, the two datasets should be well suited to learn about investors' decision making.

\section{Insert table 2 here.}


Summary statistics for the dependent and the explanatory variables can be found in table 3. The statistics are intuitively consistent and coherent. The average maximum performance fee for the two-fund case is $17.4 \%$ and the average for the share-classes is $16.8 \%$ in Study I. In Study II, the maximum performance fees are lower $(15.3 \%$ in the Performance fee group and $12.5 \%$ in the Text questions group) which is probably due to the different elicitation process. The means are significantly different from each other. The means for the text questions are all around four which is the center point of their one to seven scale. The mean loss aversion coefficient implies that our subjects are on average loss averse and the mean risk aversion certainty equivalent implies that they are also risk averse. Both of these values are in line with previous findings in the literature (cf. Tversky and Kahneman, 1992). In both studies, the average participant estimated the Euro Stoxx to move sideways; the mean estimated Euro Stoxx level in one year is around the respective index level at the time of the study. Individual estimates vary largely from zero points to 6,200 .

\section{Insert table 3 here.}

\section{Results}

Subjects in both studies are asked to choose between two funds where the only difference is the fee structure. They have to invest the full amount into one fund such that diversification is not an issue. In this scenario, an obvious potential driver of their choice could be the intention to minimize fees. As the probability for positive and negative returns as well as the conditional returns are given, the expected fees can be calculated. They can be found in table 4. In Study I, the expected fee for the management fee fund is constant at $€ 163$ while the expected performance fee ranges from $€ 39$ to $€ 470$. The $10 \%$ performance fee has approximately the same expected value as the management fee. Consequently, a fee minimizing investor should accept any performance fee up to 
$10 \%$ and reject any performance fee that is higher. In Study II, the expected fees are slightly different due to the fact that an additional annual return of the Euro Stoxx 50 was available. In the Performance fee group and in the Text questions group, the expected fee for the management fee fund is constant at $€ 161$ and the expected performance fee ranges from $€ 36$ to $€ 436$. Again, a fee minimizing investor should accept any performance fee up to $10 \%$ and reject any performance fee that is higher. In the Management fee group in Study II, subjects choose between a fixed performance fee and a changing management fee. In this group, the expected performance fee is constant at $€ 255$ while the expected management fee ranges from $€ 54$ to $€ 349$. A fee-minimizing investor would accept any management fee up to $2.25 \%$ and reject any management fee that is higher.

\section{Insert table 4 here.}

This is not what we find in the data (cf. table 3 ). The average maximum performance fee is $17.4 \%$ ( $16.8 \%$ if we do not consider the two funds but the two share classes) in Study I which is significantly different (1\%-level). In Study II, the average performance fee is also higher than $10 \%$. In the Performance fee group the average maximum performance fee is $15.3 \%$ (significant at 1\%). With $12.5 \%$ in the Text questions group it is still significantly above $10 \%$ but also significantly lower than in the Performance fee group (both at the 1\%-level). This implies that the preoccupation with reasons for and against certain fees right before the actual choice affects this choice. In the Management fee group, the average chosen management fee of $1.5 \%$ is significantly (1\%-level) lower than the fair management fee of $2.25 \%$ would be, again hinting at a preference for performance fees. A reason for this choice may be the belief that funds with performance fees perform better than those without. The right column of table 4 shows the outperformance that would just compensate the investor for the difference in expected fees; the outperformance would have to be even higher to make a net profit. In Study I 
for example, an investor accepting the $20 \%$ performance fee, would have to believe in an outperformance of $1.8 \%$. For the $30 \%$ fee, the outperformance would have to be $3.9 \%$. Note that this outperformance is not relative to the common benchmark but relative to the management fee fund which also follows an active strategy. In the following, reasons for this behavior will be analyzed in a multivariate setting separately for both Study I and Study II.

\section{Study I}

Table 5 reports Tobit regressions with maximum performance fee for the two-fund case as the dependent variable. All the Tobit models are estimated with upper and lower bound to take the limited range of the maximum performance fee into account. Column (1) of table 5 includes the basic explanatory variables. It appears that three variables are the main drivers of the maximum performance fee: outperformance, managerial risk-taking, and loss aversion. The general incentivization from a performance fee does not appear to be a driver of the maximum performance fee. The belief in an outperformance however, which should be the main effect of an incentivization, is an economically (1.94 percentage points higher performance fee per point) and statistically (1\%-level) significant driver. The fear for higher managerial risk-taking due to the incentivization scheme is equally significant but it goes in the opposite direction (1.6 percentage points lower performance fee per point). This effect should be expected as funds with performance fees are prone to increasing the fund risk (see e.g. Carpenter, 2000); subjects who are aware of this issue should incorporate it into their decision and they should choose a lower performance fee. Loss aversion elicited in text form is also a significant predictor; a higher loss aversion goes along with a 2.5 percentage points higher performance fee. Fairness and negative fairness show no significant effect implying that investors rely mainly on economic reasons. Also, loss aversion and risk aversion measured with standard lottery questions show no significant influence. This finding 
is not surprising as verbal measures are usually better suited to predict behavior than those derived from lottery questions (Nosić and Weber, 2010). Erner et al. (2012) have shown that measured prospect theory parameters have hardly any predictive power for the willingness to pay for financial products. Sautner et al. (2010) did not find any significant relation between the valuation of financial assets and risk aversion measures. The estimated Euro Stoxx level is statistically significant but the effect is economically small: if the estimated level is 1,000 points higher, the maximum performance fee is three percentage points lower.

Columns (2) to (6) of table 5 report the same regression with control variables added one at a time. Column (7) shows the full regression including all control variables. Financial literacy, education on college level, income over $€ 3,000$, age, and male gender are added. All of which have no significant influence on the maximum performance fee. Coefficients of the explanatory variables are robust to the inclusion of these control variables. For some of the control variables like financial literacy or education, an influence could have been expected. Khorana et al. (2009) hypothesize that more sophisticated investors may seek lower fees as they may be more aware of fees. As described above, our subjects have a very high financial literacy with a low variance. The low variance could explain why no effect is found: the differences between the subjects are not large enough.

\section{Insert table 5 here.}

Table 6 reports Tobit regressions with maximum performance fee for the two share classes as the dependent variable. The share classes have an identical development before fees: only the fee structure should matter in this case. As expected, outperformance and managerial risk-taking are not significant anymore. The remaining variables have the same effects as in the two-fund case. Loss aversion in text form remains statistically and economically significant (a higher loss aversion goes along with a 2.7 percentage 
points higher performance fee). Fairness, negative fairness, loss aversion coefficients, and risk aversion certainty equivalents again have no significant effects. The estimated Euro Stoxx level is not significant. Column (2) to (6) of table 6 report the same regression with control variables added one at a time. Column (7) shows the full regression including all control variables. Financial literacy, college, income over $€ 3,000$, age, and male gender still have no significant influence on the maximum performance fee. Coefficients are again robust to the inclusion of the control variables. Altogether, the analysis of the share classes supports the previous results. The impact of loss aversion on the maximum performance fee appears to result from a preference for certain monetary flows. Investors prefer paying more in a good state if negative outcomes are reduced in a bad state. The impact of outperformance and managerial risk-taking in the two-fund case appears to result from incentivization effects which are not present with the share classes.

\section{Insert table 6 here.}

Different return distributions for the two share classes have also been tested in Study I. The distribution and the conditional expected returns shown for the case of the share classes were manipulated with a mean-preserving spread. The probability of a loss was increased to $45 \%$; negative returns were reduced in magnitude and the smallest positive returns were reduced such that they became negative. The maximum performance fee for this decision context was elicited after the share-class case. For this manipulation, the average maximum performance fee rises to $18.2 \%$ (from $16.8 \%$ for the two standard share classes). This makes perfect sense as the expected payable performance fee is lower for the manipulation; the manipulation is "cheaper". Results of Tobit regressions are similar to the results for the two standard share classes. The effects described in the share-class case persist.

Following classic portfolio theory, risk and return are meant to be considered simultaneously. For this reason a relation between the belief in a better performance and 
the belief in an increased risk might exist. To test for this possibility, interaction variables between better performance and increased risk have been created and added to the models described above (not reported). The results reported above are robust to the inclusion of these variables.

\section{Study II}

The three groups in Study II see different situations. The Performance fee group is similar to the two-fund case in Study I. The Text question group has a different sequence as compared to the Performance fee group as the text questions are asked before the funds are presented. In the Management fee group, the management fee instead of the performance fee is elicited. In all three groups the fees are elicited more directly than in Study I.

Table 7 reports Tobit regressions with maximum performance fee for the Performance fee group as the dependent variable. Column (1) includes the basic explanatory variables which are slightly different from the ones used in Study I. outperformance is measured directly instead of on a 1-7 Likert scale and signalling is added as a further explanatory variable. The main explanatory variables from Study I are robust to the new elicitation of the maximum performance fee: estimated outperformance, managerial risk-taking, and loss aversion are significant predictors. The general incentivization from a performance fee is still not a driver of the maximum performance fee. The belief in an outperformance of the performance fee fund is statistically (1\%-level) significant. Economic significance is also given: for every percentage point of outperformance, a 2.7 percentage points higher performance fee is accepted. As only a part of the outperformance goes to the fund via the performance fee, this magnitude makes sense. The fear for higher mangerial risktaking is significant at the $1 \%$-level and it confirms previous results with a 2.1 percentage points lower performance fee per point. A higher loss aversion goes along with a two percentage points higher performance fee (significant at the 5\%-level). Fairness and 
negative fairness still show no significant effect. The estimated Euro Stoxx level is not statistically significant in this sample. Signalling which was added in Study II has no persistent effect.

Columns (2) to (6) of table 7 report the same regression with control variables added one at a time. Column (7) shows the full regression including all control variables. Financial literacy, education on college level, income over $€ 3,000$, age, and male gender are added. All of which have no persistent significant influence on the maximum performance fee. Male gender is only significant at the $10 \%$-level when it is included as the only control variable. Coefficients of the explanatory variables are robust to the inclusion of control variables. The analysis of the Performance fee group shows that the previous results are persistent in a different sample and with a different elicitation of the maximum performance fee. A direct measurement of the management fee and of the estimated outperformance does not lead to different results. Signalling appears to be unimportant for the choice of a fee scheme.

\section{Insert table 7 here.}

Table 8 reports Tobit regressions with maximum performance fee for the Text question group as the dependent variable. Column (1) includes the basic explanatory variables which are the same as in the other two groups of Study II. Except for managerial risk-taking, the coefficients are very similar to those of the Performance fee group. Managerial risk-taking has a higher effect: the maximum performance fee is reduced by 2.7 percentage points per point. It appears that thinking of possible reasons before taking the decision makes subjects more aware of possible risks. Thinking before the decision also leads to a behavior that is closer to the behavior of a fee-minimizing investor. This notion is supported by the different constants in the Performance fee group and the Text question group. The constant is much lower in the Text question group implying that a lower performance fee is chosen on average. Fairness, negative fairness, and signalling 
are again insignificant. The estimated Euro-Stoxx level is statistically significant at the $10 \%$-level but it is still economically insignificant. The coefficients of the explanatory variables are robust to the inclusion of the control variables in columns (2) to (7). Thinking of reasons appears to lead to a decision that is closer to the fee-minimizing decision and more aware of possible risks.

\section{Insert table 8 here.}

Table 9 reports Tobit regressions with maximum management fee for the Management fee group as the dependent variable. Column (1) includes the basic explanatory variables. This group allows to control for a different focus on the fee choice. Due to the elicitation of the maximum management fee, the coefficients are not directly comparable to those of the other groups. On the one hand, they have to have the opposite sign to support the same hypothesis. On the other hand, their magnitude should be different due to the dimension of the management fees: the management fee ranges from $.5 \%$ to $3 \%$ in steps of $.25 \%$ while the performance fee in the other groups ranges from $2.5 \%$ to $30 \%$ in steps of $2.5 \%$. The estimated outperformance of the performance fee fund is again a reason to prefer the performance fee fund, i.e. to choose a lower maximum management fee. For every percentage point of outperformance, the accepted management fee is 0.32 percentage points lower. Loss aversion remains a significant reason for the performance fee fund; a one point increase in loss aversion leads to a 0.28 percentage points lower management fee. Negative fairness becomes significant too. The focus on management fees leads to a different view on the management fees: investors fear to be treated unfairly by paying too much when the fund performs badly (statistically significant at the $1 \%$-level; the chosen management fee is reduced by 0.19 percentage points per point). Managerial risk-taking is not significant anymore. Apparently, the focus on a certain fee leads to a focus on the risks of the respective fee. For a performance fee, the risk is measured by managerial risk-taking. For management fees it is measured by negative 
fairness which is the risk to pay a fee even if the return is negative. The focus on different fee types appears to lead to different perceived risks. In the discussion, this will be considered in more detail. Estimated outperformance and loss aversion go in the same direction as in the other groups. The coefficients of the explanatory variables are also significant after the inclusion of the control variables in columns (2) to (7).

\section{Insert table 9 here.}

\section{Discussion}

We find that investors are ready to pay a premium for a performance fee fund. They accept a higher expected fee if this fee is in form of a performance fee instead of a management fee. In Study I for example, the average investor pays over $€ 100$ more for the performance fee scheme than for the management fee scheme. This amount is more than $1 \%$ of the initial investment amount of $€ 10.000$. At first glance, it appears that average investors pay too much for performance fee funds and that the industry can skim these additional fees to increase profits.

However it makes sense, that investors are ready to pay more if they believe in a better performance. We show that this idea from the previous literature is indeed an important argument for investors. While the literature has focussed on such incentive effects of performance fees, we show that other factors exist as well. Loss aversion is such a factor: Performance fees can also be beneficial because they allow to smooth returns after fees by shifting fees to a period with positive returns. While incentive effects influence net performance indirectly via the fund (management), smoothing influences net returns directly as losses and gains are reduced in size. This smoothing is especially interesting for loss averse investors. They can transfer a fee from a negative state (where it hurts them more to pay it) to a positive state (where it hurts them less). This effect is very persistent i.e it remains highly significant in all groups. The effect also persists if the 
performance fee and the outperformance are measured more directly in Study II. These findings show that performance fees are not simply a tool to increase profits but that they are also beneficial for investors.

The premium investors pay for a performance fee is reduced if investors are encouraged to think about fee schemes before taking their decision. In the text question group of Study II where this is the case, the average investor pays a premium of $€ 20$ in expected fees for the performance fee fund. The performance fee premium is reduced by around $80 \%$ and incentive effects and loss aversion can explain the remaining premium.

In both studies, it appears that investors focus on economic reasons when buying funds. Non-economic arguments like fairness towards the fund (manager) were not found to be significantly related to the decision. This is remarkable as fairness is frequently put forth as an argument for performance fees in public discussions. It appears that the fairness argument is merely a socially desirable rationalization.

Another interesting finding is the fact that investors focus on the specific risks of the fee scheme that is elicited. When the management fee is elicited in the respective group of Study II, investors focus on the main risk of a management fee: the risk to pay a fee even if the return is negative (measured by negative fairness). The risk of the performance fee, namely that the fund (management) increases the fund risk due to its option-like participation in the returns (measured by managerial risk-taking), ceases to be an important factor. When asked about different fees, investors focus on the risk of the more prominently placed fee type. This finding is in line with the previous literature. Vlaev et al. (2008) show for example that preferences depend on the attribute that can be manipulated. Nevertheless, loss aversion and expected outperformance of the performance fee fund are significant predictors in this group as well.

Our findings have implications for investors, regulators, and for the fund industry itself. The industry should not only focus on incentive effects of performance fees like 
a possible outperformance but it should also point out that performance fees allow a smoothing of net returns which is especially interesting for loss averse investors. Investors for their part should take care that they pay not too high a premium for the potential benefits of a performance fee. The fact that the premium is reduced by around $€ 80$ (or an economically important .8\% of the investment amount) if investors are encouraged to think about pros and cons of fee schemes shows that fees are worth thinking about. Regulators as mediators between the industry and the investor should keep both sides in mind. Regulations that serve to clarify fee structures could improve investors' understanding and thus be beneficial for the investor and the industry. Regulations that aim at prohibiting performance fees however, may be detrimental to both sides as both investors and the industry have potential benefits from performance fees. If incentive effects are left aside, the industry on the one hand may earn a premium but the investor on the other hand feels better due to a smoothing of his net returns. Consequently the investor pays a premium for a service and the main concern should be that this premium is not too high.

We consider mutual funds with asymmetric performance fees. However, our results are also relevant for hedge funds and funds with symmetric performance fees. Most hedge funds have an asymmetric performance fee that is similar to the fees we use. For hedge funds too, loss averse investors could prefer paying an additional performance fee for a good development over paying a higher management fee independently of the fund's performance. Consequently, our results should be transferable to all funds with asymmetric fees. This includes the majority of hedge funds and of European mutual funds with performance fees. However, the majority ${ }^{2}$ of U.S. mutual funds which have performance fees have symmetric performance fees, as only symmetric performance fees are allowed for mutual funds. For these funds, the loss aversion effect should be even

\footnotetext{
${ }^{2}$ Elton et al. (2003) address the fact that the SEC has also tolerated mutual funds with asymmetric performance fees for some time.
} 
more relevant as losses are even more attenuated. Managerial risk-taking however should be less of an issue as the fund shares the risks. Future research should address symmetric performance fees directly but altogether we expect our results to hold for these funds as well.

Another approach for future research may be a more realistic fee scheme. We used a simplified scheme to make it easy to understand the fees and easy to compute expected values of the different schemes. In the future a pure management fee could be tested against a combination of a smaller management fee and a performance fee. In this setting, the distinction between symmetric and asymmetric performance fees is very important. For asymmetric performance fees on the one hand, the loss aversion argument only works if the performance fees are accompanied by lower fixed management fees. An asymmetric performance fee on top of the normal management fee would ceteris paribus lead to a lower average net return. For symmetric performance fees on the other hand, the loss aversion argument could also work if the performance fee is charged on top of a management fee as it reduces losses not only by avoiding a fee but also by a partial refund of the losses. Another direction for future research could be the inclusion of the expected fees into the description of the funds. It is possible that the premium investors accept for a performance fee depends on the knowledge of the nominal Euro- or Dollaramount they pay in fees. This would be similar to a price-tag in a supermarket which would make it easier to estimate how much better the performance fee fund would have to perform in order to provide a net benefit. Such price-tags could help investors to avoid paying too high a fee as discussed above. Furthermore, future research has to address the fact that some performance fees are measured relative to a benchmark index. 


\section{References}

Abdellaoui, M., Bleichrodt, H., LHaridon, O., 2008. A tractable method to measure utility and loss aversion under prospect theory. Journal of Risk and Uncertainty 36 (3), $245-266$.

Baker, G. P., Jensen, M. C., Murphy, K. J., 1988. Compensation and incentives: Practice vs. theory. The Journal of Finance 43 (3), 593-616.

Barber, B., Odean, T., Zheng, L., 2005. Out of sight, out of mind: The effects of expenses on mutual fund flows. Journal of Business 78 (6), 2095-2120.

Berhold, M., 1971. A theory of linear profit-sharing incentives. Quarterly Journal of Economics 85 (3), 460-482.

Beshears, J., Choi, J. J., Laibson, D. I., Madrian, B., 2010. How does simplified disclosure affect individuals' mutual fund choices? In: Wise, D. A. (Ed.), Explorations in the Economics of Aging. The University of Chicago Press, Chicago.

Brown, K. C., Harlow, W. V., Starks, L. T., 1996. Of tournaments and temptations: An analysis of managerial incentives in the mutual fund industry. Journal of Finance $51(1), 85-110$.

Camerer, C. F., Hogarth, R. M., 1999. The effects of financial incentives in experiments: A review and capital-labor-production framework. Journal of Risk and Uncertainty $19(1-3), 7-42$.

Capon, N., Fitzsimons, G. J., Prince, R. A., 1996. An individual level analysis of the mutual fund investment decision. Journal of Financial Services Research 10 (1), 59-82.

Carhart, M. M., 1997. On persistence in mutual fund performance. Journal of Finance $52(1), 57-82$. 
Carmon, Z., Simonson, I., 1998. Price-quality trade-offs in choice versus matching: New insights into the prominence effect. Journal of Consumer Psychology 7 (4), 323-343.

Carpenter, J. N., 2000. Does option compensation increase managerial risk appetite? Journal of Finance 55 (5), 2311-2331.

Carroll, J. B., 1989. Are performance fees justified?: Yes. Financial Executive 5 (3), $26-29$.

Chevalier, J., Ellison, G., 1997. Risk taking by mutual funds as a response to incentives. Journal of Political Economy 105 (6), 1167-1200.

Choi, J. J., Laibson, D., Madrian, B. C., 2010. Why does the law of one price fail? an experiment on index mutual funds. Review of Financial Studies 23 (4), 1405-1432.

Das, S. R., Sundaram, R. K., 2002. Fee speech: Signaling, risk sharing, and the impact of fee structures on investor welfare. Review of Financial Studies 15 (5), 1465-1497.

Destatis, 2010. Statistical yearbook 2010. Tech. rep.

Deutsches Aktieninstitut, 2010. DAI factbook 2010. Tech. rep.

Ehm, C., Kaufmann, C., Weber, M., 2013. Volatility inadaptability: Investors care about risk, but can't cope with volatility. Working Paper.

Elton, E. J., Gruber, M. J., Blake, C. R., 2003. Incentive fees and mutual funds. Journal of Finance 58 (2), 779-804.

Erner, C., Klos, A., Langer, T., 2012. Can prospect theory be used to predict investor's willingness to pay? Working Paper.

Golec, J., Starks, L., 2004. Performance fee contract change and mutual fund risk. Journal of Financial Economics 73 (1), 93-118. 
Grinblatt, M., Titman, S., 1989. Adverse risk incentives and the design of performancebased contracts. Management Science 35 (7), 807-822.

Jensen, M. C., Meckling, W. H., 1976. Theory of the firm: Managerial behavior, agency costs and ownership structure. Journal of Financial Economics 3 (4), 305-360.

Kahneman, D., Tversky, A., 1979. Prospect theory: An analysis of decision under risk. Econometrica 47 (2), 263-291.

Kahneman, D., Tversky, A., 1984. Choices, values, and frames. American Psychologist 39 (4), 341-350.

Kaufmann, C., Weber, M., Haisley, E. C., 2013. The role of experience sampling and graphical displays on one's investment risk appetite. Management Science 59 (2), 323340 .

Khorana, A., Servaes, H., Tufano, P., 2009. Mutual fund fees around the world. Review of Financial Studies 22 (3), 1279-1310.

Kozup, J., Howlett, E., Pagano, M., 2008. The effects of summary information on consumer perceptions of mutual fund characteristics. Journal of Consumer Affairs 42 (1), $37-59$.

Li, C. W., Tiwari, A., 2009. Incentive contracts in delegated portfolio management. Review of Financial Studies 22 (11), 4681-4714.

Lichtenstein, S., Slovic, P., 1971. Reversals of preference between bids and choices in gambling decisions. Journal of Experimental Psychology 89 (1), 46-55.

Massa, M., Patgiri, R., 2009. Incentives and mutual fund performance: Higher performance or just higher risk taking? Review of Financial Studies 22 (5), 1777-1815. 
Müller, S., Weber, M., 2010. Financial literacy and mututal fund investments: Who buys actively managed funds? Schmalenbach Business Review 62 (2), 126-153.

Nosić, A., Weber, M., 2010. How riskily do I invest? The role of risk attitudes, risk perceptions, and overconfidence. Decision Analysis 7 (3), 282-301.

Pontari, B., Stanaland, A., Smythe, T., 2009. Regulating information disclosure in mutual fund advertising in the united states: Will consumers utilize cost information? Journal of Consumer Policy 32 (4), 333-351.

Sautner, Z., Weber, M., Glaser, M., 2010. What determines how top managers value their stock options? Working Paper.

Sirri, E. R., Tufano, P., 1998. Costly search and mutual fund flows. Journal of Finance $53(5), 1589-1622$.

Starks, L. T., 1987. Performance incentive fees: An agency theoretic approach. Journal of Financial \& Quantitative Analysis 22 (1), 17-32.

Tversky, A., Kahneman, D., 1992. Advances in prospect theory: Cumulative representation of uncertainty. Journal of Risk and Uncertainty 5 (4), 297-323.

van Rooij, M., Lusardi, A., Alessie, R., 2011. Financial literacy and stock market participation. Journal of Financial Economics 101 (2), 449-472.

Vlaev, I., Chater, N., Stewart, N., 2008. Seeing is not enough: manipulating choice options causes focusing and preference change in multiattribute risky decision-making. Journal of Behavioral Decision Making 21 (5), 556-574.

West, S., Leonard-Chambers, V., 2006. Understanding investor preferences for mutual fund information. Investment Company Institute Report. 
Wilcox, R., 2003. Bargain hunting or star gazing? Investors' preferences for stock mutual funds. Journal of Business 76 (4), 645-663.

Zamir, E., Ritov, I., 2010. Revisiting the debate over attorneys' contingent fees: A behavioral analysis. Journal of Legal Studies 39 (1), 245-288. 

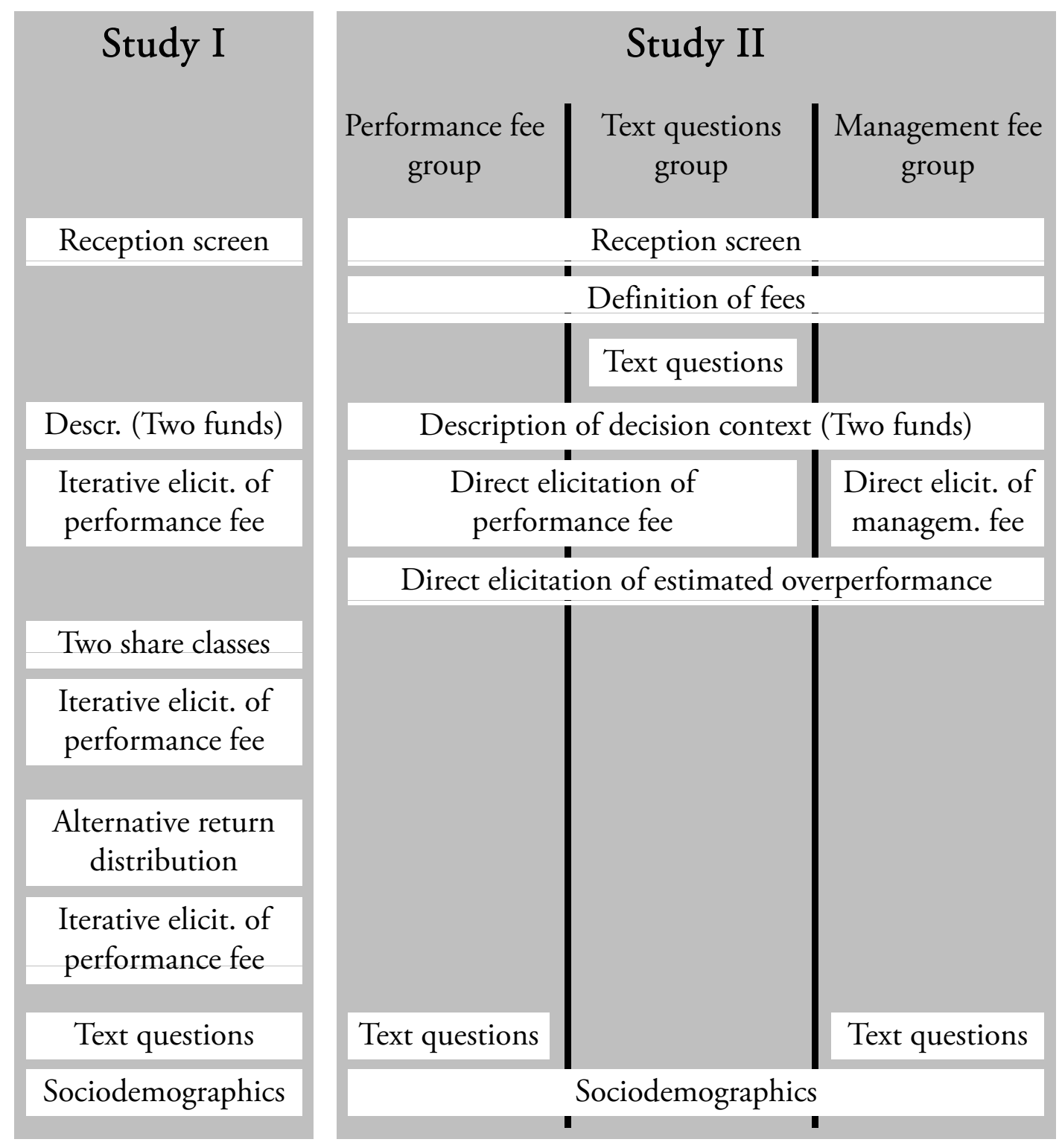

Figure 1: Design of Study I and Study II compared 


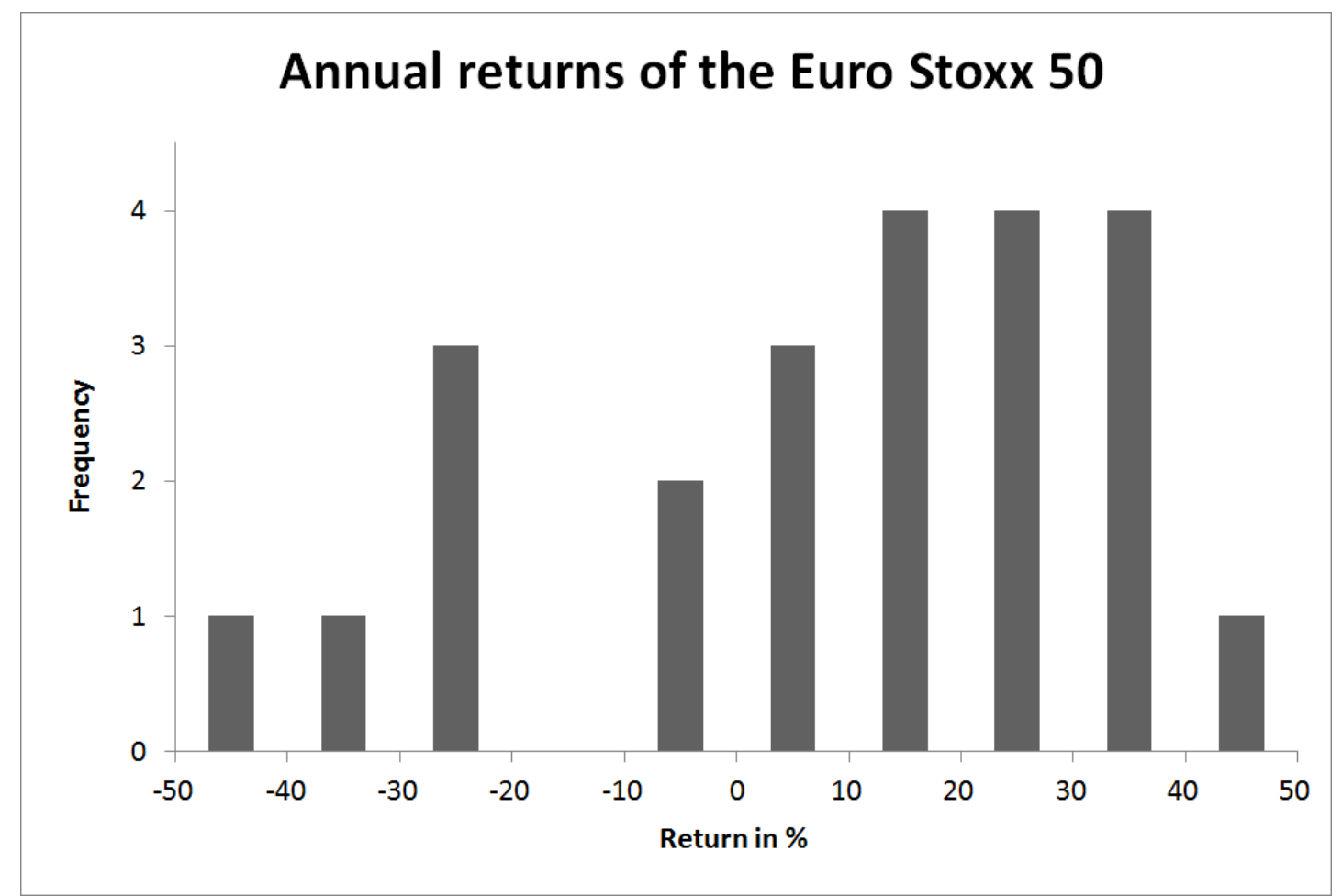

Figure 2: Histogram of the annual Euro Stoxx 50 returns since introduction This histogram reports frequencies for annual Euro Stoxx 50 returns and was provided with the explanations of the management fee fund and the performance fee fund. The same histogram with a different title ("Past annual returns of the fund") was provided for the choice between the two share classes. 
Table 1: Wording of text questions used

\begin{tabular}{|c|c|c|c|}
\hline \multirow[t]{2}{*}{ Explanatory variable } & \multirow[t]{2}{*}{ Text question } & \multicolumn{2}{|c|}{ Included in } \\
\hline & & Study I & Study II \\
\hline Manager incentives & $\begin{array}{l}\text { The performance fee assures that the } \\
\text { fund manager acts in my interest. }\end{array}$ & Yes & Yes \\
\hline Outperformance & $\begin{array}{l}\text { A performance fee will have a positive } \\
\text { impact on the return of the fund. }\end{array}$ & Yes & \\
\hline Managerial risk-taking & $\begin{array}{l}\text { There could be the risk, that a fund } \\
\text { manager invests very riskily in order to } \\
\text { benefit from gains while he suffers less } \\
\text { from disadvantages in case of losses. }\end{array}$ & Yes & Yes \\
\hline Loss aversion & $\begin{array}{l}\text { I prefer paying a higher fee in case of } \\
\text { gains, if that allows me to avoid a fee in } \\
\text { case of losses. }\end{array}$ & Yes & Yes \\
\hline Fairness & $\begin{array}{l}\text { It is fair that a fund manager partici- } \\
\text { pates in the success of the investment. }\end{array}$ & Yes & Yes \\
\hline Negative fairness & In case of losses, it is unfair to pay a fee. & Yes & Yes \\
\hline Est. Euro Stoxx level & $\begin{array}{l}\text { Please estimate the development of the } \\
\text { Euro Stoxx over the next year. What is } \\
\text { the most likely level in your opinion? }\end{array}$ & Yes & Yes \\
\hline Signalling & $\begin{array}{l}\text { With the performance fee, the fund } \\
\text { manager gives me a clear signal that he } \\
\text { is better than other fund managers. }\end{array}$ & & Yes \\
\hline
\end{tabular}

This table contains the wording of the questions that are used as explanatory variables. Responses are measured on a 1-7 Likert scale where 7 indicates strong agreement with the respective statement. The estimated Euro Stoxx level in one year was elicited as a point estimate. In Study II, the question on signalling was added and outperformance was measured directly. 
Table 2: Participants' personal characteristics

(a) Education

\begin{tabular}{lrrrrrr}
\hline & \multicolumn{2}{c}{ Study I } & \multicolumn{2}{c}{ Study II } & Germany & German investors \\
\hline High school & 39 & $(12.58 \%)$ & 13 & $(5.44 \%)$ & $65.80 \%$ & $51.00 \%$ \\
Abitur & 81 & $(26.13 \%)$ & 44 & $(18.41 \%)$ & $12.20 \%$ & $47.00 \%$ \\
University degree & 190 & $(61.29 \%)$ & 182 & $(76.15 \%)$ & $13.60 \%$ & n.a. \\
Total & 310 & & 239 & & & \\
\hline
\end{tabular}

(b) Occupation

\begin{tabular}{lrrrrrr}
\hline & \multicolumn{2}{c}{ Study I } & \multicolumn{2}{c}{ Study II } & Germany & German investors \\
\hline University student & 16 & $(4.97 \%)$ & 6 & $(2.38 \%)$ & $2.91 \%$ & $2.51 \%$ \\
Employee & 138 & $(42.86 \%)$ & 150 & $(59.52 \%)$ & $42.40 \%$ & $58.23 \%$ \\
Self-employed & 86 & $(26.71 \%)$ & 35 & $(13.89 \%)$ & $5.21 \%$ & $11.43 \%$ \\
Unemployed & 10 & $(3.11 \%)$ & 6 & $(2.38 \%)$ & $7.10 \%$ & n.a. \\
Other & 72 & $(22.36 \%)$ & 55 & $(21.83 \%)$ & $42.38 \%$ & $27.83 \%$ \\
Total & 322 & & 252 & & & \\
\hline
\end{tabular}

(c) Monthly household income

\begin{tabular}{lrrrrrr}
\hline & \multicolumn{2}{c}{ Study I } & \multicolumn{2}{c}{ Study II } & Germany & German investors \\
\hline up to $€ 1,500$ & 19 & $(9.45 \%)$ & 9 & $(4.84 \%)$ & $37.90 \%$ & $2.58 \%$ \\
$€ 1,500$ to $€ 3,000$ & 35 & $(17.41 \%)$ & 43 & $(23.12 \%)$ & $32.57 \%$ & $34.02 \%$ \\
$€ 3,000$ to $€ 4,500$ & 71 & $(35.32 \%)$ & 58 & $(31.18 \%)$ & $22.29 \%$ & $29.94 \%$ \\
$€ 4,500$ and more & 76 & $(37.81 \%)$ & 76 & $(40.86 \%)$ & $7.24 \%$ & $33.45 \%$ \\
Total & 201 & & 186 & & & \\
\hline
\end{tabular}

(d) Financial literacy, age, and gender

\begin{tabular}{lrrrr|rrrr}
\hline & \multicolumn{3}{c}{ Study I } & \multicolumn{5}{c}{ Study II } \\
& mean & sd & $\min$ & $\max$ & $\operatorname{mean}$ & sd & $\min$ & $\max$ \\
\hline Financial literacy & 9.120 & 1.270 & 0 & 10 & 9.381 & 0.904 & 6 & 10 \\
Age & 48.470 & 13.763 & 21 & 84 & 48.051 & 13.175 & 20 & 82 \\
Male gender & 0.886 & & & & 0.921 & & & \\
\hline
\end{tabular}

Table 2(a) to 2(c) show the absolute number of participants with a certain education, occupation, and income in both studies. Relative numbers are in brackets. Data in the row "Germany" is from Destatis (2010) and data in "German investors" is from the DAI factbook (Deutsches Aktieninstitut, 2010). Table 2(a) shows participants' education. German school types differ somewhat from international school types. Abitur is comparable to high school diploma plus university entrance exam. Subjects are highly educated compared to the German average. Table 2(b) illustrates the occupation of the subjects. An above average number is self-employed. Table 2(c) illustrates the income of the subjects. Many subjects are above the mean income group (German average according to Destatis $(2010)$ : $€ 3,141$ ). Table 2(d) shows financial literacy after van Rooij et al. (2011), age, and gender of the participants for both studies. Financial literacy is above average and the sample mainly consists of men. Altogether, deviations from the German average all go in one direction; the average participant should be better able to judge and to succeed in financial decisions than the average German. 
Table 3: Summary statistics

\begin{tabular}{|c|c|c|c|c|}
\hline & Study I & Group 1 & $\begin{array}{l}\text { Study II } \\
\text { Group } 2\end{array}$ & Group 3 \\
\hline Maximum performance fee & $\begin{array}{l}17.38 \\
(9.19)\end{array}$ & $\begin{array}{c}15.3 \\
(9.13)\end{array}$ & & $\begin{array}{c}12.5 \\
(9.34)\end{array}$ \\
\hline Max. perf. fee (share classes) & $\begin{array}{l}16.77 \\
(9.28)\end{array}$ & & & \\
\hline Maximum management fee & & & $\begin{array}{l}1.492 \\
(0.84)\end{array}$ & \\
\hline Manager incentives & $\begin{array}{l}3.975 \\
(2.00)\end{array}$ & $\begin{array}{l}4.524 \\
(1.89)\end{array}$ & $\begin{array}{l}4.622 \\
(1.66)\end{array}$ & $\begin{array}{l}4.409 \\
(1.99)\end{array}$ \\
\hline Outperformance & $\begin{array}{c}3.623 \\
(1.90)\end{array}$ & & & \\
\hline Est. outperformance & & $\begin{array}{l}0.661 \\
(1.77)\end{array}$ & $\begin{array}{c}0.22 \\
(0.95)\end{array}$ & $\begin{array}{c}0.46 \\
(1.80)\end{array}$ \\
\hline Managerial risk-taking & $\begin{array}{l}3.761 \\
(1.91)\end{array}$ & $\begin{array}{l}4.317 \\
(1.68)\end{array}$ & $\begin{array}{l}4.767 \\
(1.38)\end{array}$ & $\begin{array}{l}3.955 \\
(1.89)\end{array}$ \\
\hline Loss aversion & $\begin{array}{l}4.279 \\
(2.01)\end{array}$ & $\begin{array}{l}4.463 \\
(1.98)\end{array}$ & $\begin{array}{l}4.678 \\
(1.65)\end{array}$ & $\begin{array}{l}4.205 \\
(2.02)\end{array}$ \\
\hline Loss aversion coeff. & $\begin{array}{c}3.646 \\
(1.83)\end{array}$ & & & \\
\hline Risk av. certainty equiv. & $\begin{array}{c}156.5 \\
(99.31)\end{array}$ & & & \\
\hline Fairness & $\begin{array}{l}4.101 \\
(2.07)\end{array}$ & $\begin{array}{l}4.524 \\
(1.82)\end{array}$ & $\begin{array}{l}4.911 \\
(1.56)\end{array}$ & $\begin{array}{l}4.455 \\
(1.97)\end{array}$ \\
\hline Negative fairness & $\begin{array}{l}3.914 \\
(2.07)\end{array}$ & $\begin{array}{l}4.512 \\
(2.03)\end{array}$ & $\begin{array}{c}4.4 \\
(1.86)\end{array}$ & $\begin{array}{l}4.034 \\
(2.18)\end{array}$ \\
\hline Est. Euro Stoxx level & $\begin{array}{c}2791.3 \\
(575.00)\end{array}$ & $\begin{array}{c}2579.4 \\
(375.70)\end{array}$ & $\begin{array}{c}2639.6 \\
(229.00)\end{array}$ & $\begin{array}{c}2548.4 \\
(340.10)\end{array}$ \\
\hline Signalling & & $\begin{array}{l}3.817 \\
(1.94)\end{array}$ & $\begin{array}{c}3.656 \\
(1.99)\end{array}$ & $\begin{array}{c}3.057 \\
(1.99)\end{array}$ \\
\hline
\end{tabular}

This table reports the means (standard deviations are in brackets) for the maximum chosen performance fees and the main explanatory variables for Study I as well as for the Performance fee group (group 1), the Text questions group (group 2), and the Management fee group (group 3) of Study II. The mean maximum performance fee for the two-fund case is above the minimum expected fee of $10 \%$. Apparently, subjects have other reasons to chose performance fees than a pure minimization of the expected fees. The mean for the share classes is somewhat lower (the difference is statistically significant), which makes sense as incentives of the fund manager should not play a role here. Nevertheless the mean is still above $10 \%$ implying that there could be reasons other than incentives or fee minimization. The same is true for and for the Text questions group implying that subjects who think about reasons first choose differently. The explanatory variables from the text questions are all around four which is the midpoint of the 1-7 scale (with 7 meaning "Strong agreement"). The loss aversion and risk aversion measures imply that the average subject is loss averse and risk averse. The average subjects is neither optimistic nor pessimistic about the future development of the Euro Stoxx 50. 
Table 4: Expected fees

(a) Study I

\begin{tabular}{lr|lr|r|l}
\hline $\begin{array}{l}\text { Management } \\
\text { fee }\end{array}$ & $E(f e e)$ & $\begin{array}{l}\text { Performance } \\
\text { fee }\end{array}$ & $E($ fee $)$ & Difference & $\begin{array}{l}\text { Necessary out- } \\
\text { performance of } \\
\text { performance } \\
\text { fee fund }\end{array}$ \\
& & & & & \\
& $€ 163.08$ & $2.5 \%$ & $€ 39.20$ & $€ 123.88$ & $-1.3 \%$ \\
& $5.0 \%$ & $€ 78.40$ & $€ 84.68$ & $-0.9 \%$ \\
& $7.5 \%$ & $€ 117.60$ & $€ 45.48$ & $-0.5 \%$ \\
& $10.0 \%$ & $€ 156.80$ & $€ 6.28$ & $-0.1 \%$ \\
& $12.5 \%$ & $€ 196.00$ & $€-32.92$ & $0.4 \%$ \\
& $15.0 \%$ & $€ 235.20$ & $€-72.12$ & $0.8 \%$ \\
& $17.5 \%$ & $€ 274.40$ & $€-111.32$ & $1.3 \%$ \\
& $20.0 \%$ & $€ 313.60$ & $€-150.52$ & $1.8 \%$ \\
& $22.5 \%$ & $€ 352.80$ & $€-189.72$ & $2.3 \%$ \\
& $25.0 \%$ & $€ 392.00$ & $€-228.92$ & $2.8 \%$ \\
& $27.5 \%$ & $€ 431.20$ & $€-268.12$ & $3.3 \%$ \\
& $30.0 \%$ & $€ 470.40$ & $€-307.32$ & $3.9 \%$ \\
\hline
\end{tabular}

(b) Study II - Performance fee group 83 Text questions group

\begin{tabular}{ll|lr|r|l}
\hline $\begin{array}{l}\text { Management } \\
\text { fee }\end{array}$ & $E($ fee $)$ & $\begin{array}{l}\text { Performance } \\
\text { fee }\end{array}$ & $E($ fee $)$ & Difference & $\begin{array}{l}\text { Necessary out- } \\
\text { performance of } \\
\text { performance } \\
\text { fee fund }\end{array}$ \\
& & & & & \\
& $€ 161.03$ & $2.5 \%$ & $€ 36.39$ & $€ 124.64$ & $-1.2 \%$ \\
& $5.0 \%$ & $€ 72.78$ & $€ 88.25$ & $-0.9 \%$ \\
& $7.5 \%$ & $€ 109.17$ & $€ 51.86$ & $-0.5 \%$ \\
& $10.0 \%$ & $€ 145.56$ & $€ 15.47$ & $-0.2 \%$ \\
& $12.5 \%$ & $€ 181.95$ & $€-20.92$ & $0.2 \%$ \\
& $15.0 \%$ & $€ 218.34$ & $€-57.31$ & $0.6 \%$ \\
& $17.5 \%$ & $€ 254.73$ & $€-93.70$ & $0.9 \%$ \\
& $20.0 \%$ & $€ 291.12$ & $€-130.09$ & $1.3 \%$ \\
& $22.5 \%$ & $€ 327.51$ & $€-166.48$ & $1.7 \%$ \\
& $25.0 \%$ & $€ 363.90$ & $€-202.87$ & $2.0 \%$ \\
& $27.5 \%$ & $€ 400.29$ & $€-239.26$ & $2.4 \%$ \\
& $30.0 \%$ & $€ 436.68$ & $€-275.65$ & $2.8 \%$ \\
\hline
\end{tabular}


Table 4: Expected fees (continued)

(c) Study II - Management fee group

\begin{tabular}{|c|c|c|c|c|c|}
\hline $\begin{array}{l}\text { Management } \\
\text { fee }\end{array}$ & $\mathrm{E}($ fee $)$ & $\begin{array}{l}\text { Performance } \\
\text { fee }\end{array}$ & $\mathrm{E}($ fee $)$ & Difference & $\begin{array}{l}\text { Necessary out- } \\
\text { performance of } \\
\text { performance } \\
\text { fee fund }\end{array}$ \\
\hline $0.50 \%$ & $€ 53.68$ & $17.5 \%$ & $€ 254.73$ & $€-201.05$ & $2.0 \%$ \\
\hline $0.75 \%$ & $€ 80.51$ & & & $€-174.21$ & $1.7 \%$ \\
\hline $1.00 \%$ & $€ 107.35$ & & & $€-147.38$ & $1.5 \%$ \\
\hline $1.25 \%$ & $€ 134.19$ & & & $€-120.54$ & $1.2 \%$ \\
\hline $1.50 \%$ & $€ 161.03$ & & & $€-93.70$ & $0.9 \%$ \\
\hline $1.75 \%$ & $€ 187.87$ & & & $€-66.86$ & $0.7 \%$ \\
\hline $2.00 \%$ & $€ 214.71$ & & & $€-40.02$ & $0.4 \%$ \\
\hline $2.25 \%$ & $€ 241.54$ & & & $€-13.18$ & $0.1 \%$ \\
\hline $2.50 \%$ & $€ 268.38$ & & & $€ 13.65$ & $-0.1 \%$ \\
\hline $2.75 \%$ & $€ 295.22$ & & & $€ 40.49$ & $-0.4 \%$ \\
\hline $3.00 \%$ & $€ 322.06$ & & & $€ 67.33$ & $-0.7 \%$ \\
\hline $3.25 \%$ & $€ 348.90$ & & & $€ 94.17$ & $-0.9 \%$ \\
\hline
\end{tabular}

This table reports the expected fees an investor has to pay depending on the chosen fee structure. These fees are calculated using the probability for positive and negative returns as well as the conditional returns (which are also given to the subjects). Table 4(a) shows the expected fees for Study I, table 4(b) shows the expected fees for the Performance fee group and the Text questions group in Study II, and table 4(c) shows the fees for the Management fee group in Study II. The $10 \%$ performance fee has approximately the same expected value as the management fee. Consequently, a purely fee minimizing investor should accept any performance fee up to $10 \%$ and reject any performance fee that is higher. In the Management fee group, a fee minimizing investor should accept any management fee up to $2.25 \%$. The rightmost column shows the outperformance which the performance fee fund would need in order to perform as good after fees as the management fee fund. For the investor to have a net benefit, the outperformance would have to be even higher. 
Table 5: Tobit model for Study I explaining maximum performance fee (two-fund case)

\begin{tabular}{|c|c|c|c|c|c|c|c|}
\hline & (1) & $(2)$ & $(3)$ & (4) & $(5)$ & (6) & $(7)$ \\
\hline Manager incentives & $\begin{array}{l}-0.225 \\
(0.556)\end{array}$ & $\begin{array}{l}-0.227 \\
(0.556)\end{array}$ & $\begin{array}{l}-0.220 \\
(0.567)\end{array}$ & $\begin{array}{c}0.249 \\
(0.627)\end{array}$ & $\begin{array}{l}-0.324 \\
(0.560)\end{array}$ & $\begin{array}{l}-0.181 \\
(0.565)\end{array}$ & $\begin{array}{c}0.272 \\
(0.649)\end{array}$ \\
\hline Outperformance & $\begin{array}{c}1.933^{* * *} \\
(0.544)\end{array}$ & $\begin{array}{c}1.945^{* * *} \\
(0.546)\end{array}$ & $\begin{array}{c}1.871^{* * *} \\
(0.558)\end{array}$ & $\begin{array}{l}1.599^{* *} \\
(0.621)\end{array}$ & $\begin{array}{c}2.031^{* * *} \\
(0.547)\end{array}$ & $\begin{array}{c}1.931^{* * *} \\
(0.558)\end{array}$ & $\begin{array}{l}1.546^{* *} \\
(0.652)\end{array}$ \\
\hline Managerial risk-taking & $\begin{array}{c}-1.624^{* * *} \\
(0.410)\end{array}$ & $\begin{array}{c}-1.626^{* * *} \\
(0.410)\end{array}$ & $\begin{array}{c}-1.519^{* * *} \\
(0.419)\end{array}$ & $\begin{array}{c}-1.783^{* * *} \\
(0.484)\end{array}$ & $\begin{array}{c}-1.572^{* * *} \\
(0.414)\end{array}$ & $\begin{array}{c}-1.645^{* * *} \\
(0.417)\end{array}$ & $\begin{array}{c}-1.650^{* * *} \\
(0.505)\end{array}$ \\
\hline Loss aversion & $\begin{array}{c}2.482^{* * *} \\
(0.403)\end{array}$ & $\begin{array}{c}2.485^{* * *} \\
(0.403)\end{array}$ & $\begin{array}{c}2.489^{* * *} \\
(0.415)\end{array}$ & $\begin{array}{c}2.166^{* * *} \\
(0.449)\end{array}$ & $\begin{array}{c}2.484^{* * *} \\
(0.406)\end{array}$ & $\begin{array}{c}2.474^{* * *} \\
(0.412)\end{array}$ & $\begin{array}{c}2.127^{* * *} \\
(0.465)\end{array}$ \\
\hline Loss aversion coeff. & $\begin{array}{c}0.139 \\
(0.340)\end{array}$ & $\begin{array}{c}0.150 \\
(0.342)\end{array}$ & $\begin{array}{c}0.117 \\
(0.352)\end{array}$ & $\begin{array}{c}0.223 \\
(0.377)\end{array}$ & $\begin{array}{c}0.102 \\
(0.343)\end{array}$ & $\begin{array}{c}0.184 \\
(0.351)\end{array}$ & $\begin{array}{c}0.176 \\
(0.404)\end{array}$ \\
\hline Risk av. cert. equiv. & $\begin{array}{c}0.004 \\
(0.006)\end{array}$ & $\begin{array}{c}0.003 \\
(0.006)\end{array}$ & $\begin{array}{c}0.002 \\
(0.007)\end{array}$ & $\begin{array}{c}0.002 \\
(0.007)\end{array}$ & $\begin{array}{c}0.006 \\
(0.007)\end{array}$ & $\begin{array}{c}0.002 \\
(0.007)\end{array}$ & $\begin{array}{c}0.003 \\
(0.008)\end{array}$ \\
\hline Fairness & $\begin{array}{c}0.003 \\
(0.466)\end{array}$ & $\begin{array}{l}-0.015 \\
(0.469)\end{array}$ & $\begin{array}{c}0.012 \\
(0.480)\end{array}$ & $\begin{array}{c}0.155 \\
(0.531)\end{array}$ & $\begin{array}{c}0.005 \\
(0.471)\end{array}$ & $\begin{array}{l}-0.025 \\
(0.473)\end{array}$ & $\begin{array}{c}0.217 \\
(0.555)\end{array}$ \\
\hline Negative fairness & $\begin{array}{l}-0.144 \\
(0.420)\end{array}$ & $\begin{array}{l}-0.127 \\
(0.424)\end{array}$ & $\begin{array}{l}-0.164 \\
(0.437)\end{array}$ & $\begin{array}{c}-0.237 \\
(0.470)\end{array}$ & $\begin{array}{l}-0.235 \\
(0.424)\end{array}$ & $\begin{array}{l}-0.118 \\
(0.431)\end{array}$ & $\begin{array}{c}-0.349 \\
(0.508)\end{array}$ \\
\hline Est. Euro Stoxx level & $\begin{array}{c}-0.003^{* *} \\
(0.001)\end{array}$ & $\begin{array}{c}-0.003^{* *} \\
(0.001)\end{array}$ & $\begin{array}{c}-0.003^{* *} \\
(0.001)\end{array}$ & $\begin{array}{c}-0.003^{* * *} \\
(0.001)\end{array}$ & $\begin{array}{c}-0.003^{* * *} \\
(0.001)\end{array}$ & $\begin{array}{c}-0.002^{* *} \\
(0.001)\end{array}$ & $\begin{array}{c}-0.004^{* * *} \\
(0.001)\end{array}$ \\
\hline Financial literacy & & $\begin{array}{c}0.128 \\
(0.430)\end{array}$ & & & & & $\begin{array}{c}0.039 \\
(0.518)\end{array}$ \\
\hline College & & & $\begin{array}{c}-0.141 \\
(1.271)\end{array}$ & & & & $\begin{array}{l}-0.053 \\
(1.481)\end{array}$ \\
\hline Income over 3000 EUR & & & & $\begin{array}{c}-0.706 \\
(1.312)\end{array}$ & & & $\begin{array}{l}-0.877 \\
(1.492)\end{array}$ \\
\hline Age & & & & & $\begin{array}{c}0.050 \\
(0.046)\end{array}$ & & $\begin{array}{c}0.052 \\
(0.054)\end{array}$ \\
\hline Male gender & & & & & & $\begin{array}{c}1.623 \\
(1.966)\end{array}$ & $\begin{array}{l}-1.043 \\
(2.266)\end{array}$ \\
\hline Constant & $\begin{array}{c}14.154^{* * *} \\
(3.851)\end{array}$ & $\begin{array}{c}12.986^{* *} \\
(5.505)\end{array}$ & $\begin{array}{c}14.651^{* * *} \\
(4.038)\end{array}$ & $\begin{array}{c}17.863^{* * *} \\
(4.331)\end{array}$ & $\begin{array}{c}12.930^{* * *} \\
(4.424)\end{array}$ & $\begin{array}{c}12.246^{* * *} \\
(4.342)\end{array}$ & $\begin{array}{c}16.439^{* *} \\
(7.288)\end{array}$ \\
\hline Observations & 325 & 325 & 309 & 248 & 320 & 315 & 230 \\
\hline
\end{tabular}

This table reports results for Tobit regressions on maximum performance fee for the two-fund case of Study I. Besides outperformance and managerial risk-taking, loss aversion is the main explanatory variable. Fairness appears to be irrelevant. The inclusion of control variables does not affect the results. Standard errors are in parentheses. ${ }^{*}$ indicates significance at the $10 \%$-level, ${ }^{* *}$ at the $5 \%$-level, and ${ }^{* * *}$ at the $1 \%$-level. 
Table 6: Tobit model for Study I explaining maximum performance fee (share classes)

\begin{tabular}{|c|c|c|c|c|c|c|c|}
\hline & (1) & $(2)$ & $(3)$ & (4) & $(5)$ & (6) & (7) \\
\hline Manager incentives & $\begin{array}{l}-0.977^{*} \\
(0.583)\end{array}$ & $\begin{array}{c}-0.979^{*} \\
(0.583)\end{array}$ & $\begin{array}{l}-0.986^{*} \\
(0.587)\end{array}$ & $\begin{array}{l}-0.820 \\
(0.686)\end{array}$ & $\begin{array}{l}-1.066^{*} \\
(0.586)\end{array}$ & $\begin{array}{l}-0.831 \\
(0.587)\end{array}$ & $\begin{array}{l}-0.760 \\
(0.694)\end{array}$ \\
\hline Outperformance & $\begin{array}{c}0.846 \\
(0.565)\end{array}$ & $\begin{array}{c}0.855 \\
(0.566)\end{array}$ & $\begin{array}{c}0.764 \\
(0.572)\end{array}$ & $\begin{array}{c}0.533 \\
(0.675)\end{array}$ & $\begin{array}{c}0.888 \\
(0.567)\end{array}$ & $\begin{array}{c}0.660 \\
(0.575)\end{array}$ & $\begin{array}{c}0.362 \\
(0.694)\end{array}$ \\
\hline Managerial risk-taking & $\begin{array}{c}-0.825^{*} \\
(0.421)\end{array}$ & $\begin{array}{c}-0.826^{*} \\
(0.421)\end{array}$ & $\begin{array}{c}-0.769^{*} \\
(0.426)\end{array}$ & $\begin{array}{c}-0.774 \\
(0.517)\end{array}$ & $\begin{array}{c}-0.811^{*} \\
(0.425)\end{array}$ & $\begin{array}{l}-0.823^{*} \\
(0.425)\end{array}$ & $\begin{array}{l}-0.674 \\
(0.528)\end{array}$ \\
\hline Loss aversion & $\begin{array}{c}2.655^{* * *} \\
(0.422)\end{array}$ & $\begin{array}{c}2.658^{* * *} \\
(0.422)\end{array}$ & $\begin{array}{c}2.648^{* * *} \\
(0.429)\end{array}$ & $\begin{array}{c}2.160^{* * *} \\
(0.491)\end{array}$ & $\begin{array}{c}2.643^{* * *} \\
(0.424)\end{array}$ & $\begin{array}{c}2.660^{* * *} \\
(0.428)\end{array}$ & $\begin{array}{c}2.216^{* * *} \\
(0.498)\end{array}$ \\
\hline Loss aversion coeff. & $\begin{array}{c}0.186 \\
(0.355)\end{array}$ & $\begin{array}{c}0.194 \\
(0.357)\end{array}$ & $\begin{array}{c}0.158 \\
(0.363)\end{array}$ & $\begin{array}{c}-0.036 \\
(0.411)\end{array}$ & $\begin{array}{c}0.186 \\
(0.358)\end{array}$ & $\begin{array}{c}0.163 \\
(0.364)\end{array}$ & $\begin{array}{l}-0.125 \\
(0.431)\end{array}$ \\
\hline Risk av. cert. equiv. & $\begin{array}{l}-0.007 \\
(0.007)\end{array}$ & $\begin{array}{c}-0.007 \\
(0.007)\end{array}$ & $\begin{array}{c}-0.007 \\
(0.007)\end{array}$ & $\begin{array}{l}-0.008 \\
(0.008)\end{array}$ & $\begin{array}{l}-0.005 \\
(0.007)\end{array}$ & $\begin{array}{l}-0.007 \\
(0.007)\end{array}$ & $\begin{array}{l}-0.007 \\
(0.009)\end{array}$ \\
\hline Fairness & $\begin{array}{c}0.139 \\
(0.489)\end{array}$ & $\begin{array}{c}0.126 \\
(0.493)\end{array}$ & $\begin{array}{c}0.143 \\
(0.497)\end{array}$ & $\begin{array}{c}0.241 \\
(0.582)\end{array}$ & $\begin{array}{c}0.193 \\
(0.494)\end{array}$ & $\begin{array}{c}0.161 \\
(0.493)\end{array}$ & $\begin{array}{c}0.259 \\
(0.595)\end{array}$ \\
\hline Negative fairness & $\begin{array}{l}-0.051 \\
(0.436)\end{array}$ & $\begin{array}{l}-0.038 \\
(0.440)\end{array}$ & $\begin{array}{c}0.028 \\
(0.447)\end{array}$ & $\begin{array}{c}0.057 \\
(0.511)\end{array}$ & $\begin{array}{l}-0.139 \\
(0.440)\end{array}$ & $\begin{array}{l}-0.023 \\
(0.444)\end{array}$ & $\begin{array}{c}0.065 \\
(0.539)\end{array}$ \\
\hline Est. Euro Stoxx level & $\begin{array}{c}-0.002 \\
(0.001)\end{array}$ & $\begin{array}{c}-0.002 \\
(0.001)\end{array}$ & $\begin{array}{c}-0.002 \\
(0.001)\end{array}$ & $\begin{array}{l}-0.002^{*} \\
(0.001)\end{array}$ & $\begin{array}{c}-0.002 \\
(0.001)\end{array}$ & $\begin{array}{c}-0.002 \\
(0.001)\end{array}$ & $\begin{array}{c}-0.003^{* *} \\
(0.001)\end{array}$ \\
\hline Financial literacy & & $\begin{array}{c}0.098 \\
(0.449)\end{array}$ & & & & & $\begin{array}{c}0.479 \\
(0.551)\end{array}$ \\
\hline College & & & $\begin{array}{c}-0.347 \\
(1.313)\end{array}$ & & & & $\begin{array}{c}0.255 \\
(1.582)\end{array}$ \\
\hline Income over 3000 EUR & & & & $\begin{array}{c}-0.992 \\
(1.430)\end{array}$ & & & $\begin{array}{l}-1.303 \\
(1.594)\end{array}$ \\
\hline Age & & & & & $\begin{array}{c}0.011 \\
(0.048)\end{array}$ & & $\begin{array}{c}0.041 \\
(0.058)\end{array}$ \\
\hline Male gender & & & & & & $\begin{array}{c}0.282 \\
(2.035)\end{array}$ & $\begin{array}{l}-2.355 \\
(2.426)\end{array}$ \\
\hline Constant & $\begin{array}{c}14.388^{* * *} \\
(4.007)\end{array}$ & $\begin{array}{c}13.485^{* *} \\
(5.773)\end{array}$ & $\begin{array}{c}15.040^{* * *} \\
(4.151)\end{array}$ & $\begin{array}{c}19.428^{* * *} \\
(4.689)\end{array}$ & $\begin{array}{c}14.263^{* * *} \\
(4.588)\end{array}$ & $\begin{array}{c}14.146^{* * *} \\
(4.482)\end{array}$ & $\begin{array}{c}15.916^{* *} \\
(7.731)\end{array}$ \\
\hline Observations & 325 & 325 & 309 & 248 & 320 & 315 & 230 \\
\hline
\end{tabular}

This table reports Tobit regressions on maximum performance fee for the two share classes. As expected due to the irrelevance of the fee choice for the incentives of the fund (manager), outperformance and managerial risk-taking are not significant anymore. Loss aversion however remains a main explanatory variable. Fairness remains irrelevant. The inclusion of control variables does not affect the results. Standard errors are in parentheses. ${ }^{*}$ indicates significance at the $10 \%$-level, ${ }^{* *}$ at the $5 \%$-level, and ${ }^{* * *}$ at the $1 \%$-level. 
Table 7: Tobit model for Study II (Performance fee group)

\begin{tabular}{|c|c|c|c|c|c|c|c|}
\hline & (1) & $(2)$ & $(3)$ & (4) & $(5)$ & (6) & (7) \\
\hline Manager incentives & $\begin{array}{l}-0.963 \\
(1.400)\end{array}$ & $\begin{array}{l}-1.000 \\
(1.421)\end{array}$ & $\begin{array}{l}-1.329 \\
(1.437)\end{array}$ & $\begin{array}{c}-0.656 \\
(1.421)\end{array}$ & $\begin{array}{l}-0.930 \\
(1.396)\end{array}$ & $\begin{array}{c}-0.742 \\
(1.383)\end{array}$ & $\begin{array}{c}-0.842 \\
(1.466)\end{array}$ \\
\hline Est. outperformance & $\begin{array}{c}2.719^{* * *} \\
(0.788)\end{array}$ & $\begin{array}{c}2.729^{* * *} \\
(0.793)\end{array}$ & $\begin{array}{c}2.820^{* * *} \\
(0.804)\end{array}$ & $\begin{array}{c}2.651^{* * *} \\
(0.789)\end{array}$ & $\begin{array}{c}2.763^{* * *} \\
(0.787)\end{array}$ & $\begin{array}{c}2.646^{* * *} \\
(0.828)\end{array}$ & $\begin{array}{r}2.783^{* * *} \\
(0.852)\end{array}$ \\
\hline Managerial risk-taking & $\begin{array}{c}-2.072^{* * *} \\
(0.748)\end{array}$ & $\begin{array}{c}-2.079^{* * *} \\
(0.749)\end{array}$ & $\begin{array}{c}-1.947^{* *} \\
(0.752)\end{array}$ & $\begin{array}{c}-2.232^{\text {*** }} \\
(0.760)\end{array}$ & $\begin{array}{c}-2.184^{* * *} \\
(0.768)\end{array}$ & $\begin{array}{c}-2.097^{\text {*** }} \\
(0.738)\end{array}$ & $\begin{array}{r}-2.290^{* * *} \\
(0.777)\end{array}$ \\
\hline Loss aversion & $\begin{array}{l}1.979^{* *} \\
(0.888)\end{array}$ & $\begin{array}{l}1.979^{* *} \\
(0.888)\end{array}$ & $\begin{array}{l}1.868^{* *} \\
(0.889)\end{array}$ & $\begin{array}{l}1.886^{* *} \\
(0.887)\end{array}$ & $\begin{array}{l}1.888^{* *} \\
(0.896)\end{array}$ & $\begin{array}{l}2.181^{* *} \\
(0.885)\end{array}$ & $\begin{array}{l}1.889^{* *} \\
(0.899)\end{array}$ \\
\hline Fairness & $\begin{array}{c}2.222 \\
(1.655)\end{array}$ & $\begin{array}{c}2.257 \\
(1.671)\end{array}$ & $\begin{array}{c}2.651 \\
(1.701)\end{array}$ & $\begin{array}{c}2.010 \\
(1.658)\end{array}$ & $\begin{array}{c}2.234 \\
(1.649)\end{array}$ & $\begin{array}{c}2.128 \\
(1.629)\end{array}$ & $\begin{array}{c}2.416 \\
(1.705)\end{array}$ \\
\hline Negative fairness & $\begin{array}{l}-0.025 \\
(0.755)\end{array}$ & $\begin{array}{l}-0.001 \\
(0.771)\end{array}$ & $\begin{array}{c}0.070 \\
(0.757)\end{array}$ & $\begin{array}{l}-0.082 \\
(0.754)\end{array}$ & $\begin{array}{c}0.134 \\
(0.796)\end{array}$ & $\begin{array}{l}-0.218 \\
(0.753)\end{array}$ & $\begin{array}{c}0.076 \\
(0.824)\end{array}$ \\
\hline Est. Euro Stoxx level & $\begin{array}{l}-0.002 \\
(0.003)\end{array}$ & $\begin{array}{l}-0.002 \\
(0.003)\end{array}$ & $\begin{array}{l}-0.001 \\
(0.003)\end{array}$ & $\begin{array}{l}-0.002 \\
(0.003)\end{array}$ & $\begin{array}{l}-0.001 \\
(0.003)\end{array}$ & $\begin{array}{l}-0.002 \\
(0.003)\end{array}$ & $\begin{array}{l}-0.001 \\
(0.003)\end{array}$ \\
\hline Signalling & $\begin{array}{l}-1.661 \\
(1.063)\end{array}$ & $\begin{array}{l}-1.665 \\
(1.063)\end{array}$ & $\begin{array}{l}-1.766 \\
(1.062)\end{array}$ & $\begin{array}{l}-1.591 \\
(1.059)\end{array}$ & $\begin{array}{l}-1.731 \\
(1.066)\end{array}$ & $\begin{array}{c}-1.808^{*} \\
(1.052)\end{array}$ & $\begin{array}{l}-1.913^{*} \\
(1.055)\end{array}$ \\
\hline Financial literacy & & $\begin{array}{c}0.181 \\
(1.193)\end{array}$ & & & & & $\begin{array}{c}0.526 \\
(1.190)\end{array}$ \\
\hline College & & & $\begin{array}{l}-2.604 \\
(2.552)\end{array}$ & & & & $\begin{array}{l}-2.088 \\
(2.553)\end{array}$ \\
\hline Income over 3000 EUR & & & & $\begin{array}{l}-2.534 \\
(2.359)\end{array}$ & & & $\begin{array}{l}-2.305 \\
(2.314)\end{array}$ \\
\hline Age & & & & & $\begin{array}{l}-0.053 \\
(0.086)\end{array}$ & & $\begin{array}{l}-0.062 \\
(0.085)\end{array}$ \\
\hline Male gender & & & & & & $\begin{array}{c}-6.873^{*} \\
(4.087)\end{array}$ & $\begin{array}{l}-6.333 \\
(4.090)\end{array}$ \\
\hline Constant & $\begin{array}{c}19.324^{* *} \\
(8.514)\end{array}$ & $\begin{array}{c}17.664 \\
(13.872)\end{array}$ & $\begin{array}{c}18.706^{* *} \\
(8.483)\end{array}$ & $\begin{array}{c}21.181^{* *} \\
(8.648)\end{array}$ & $\begin{array}{c}21.668^{* *} \\
(9.294)\end{array}$ & $\begin{array}{c}25.928^{* * *} \\
(9.259)\end{array}$ & $\begin{array}{l}24.480^{*} \\
(14.145)\end{array}$ \\
\hline Observations & 82 & 82 & 82 & 82 & 82 & 81 & 81 \\
\hline
\end{tabular}

This table reports Tobit regressions on maximum performance fee for the Performance fee group of Study II. The results support the findings from the two-fund case of Study I. Estimated outperformance, managerial risk-taking and loss aversion are found to be significant predictors. ${ }^{*}$ indicates significance at the $10 \%$-level, ${ }^{* *}$ at the $5 \%$-level, and ${ }^{* * *}$ at the $1 \%$-level. 
Table 8: Tobit model for Study II (Text questions group)

\begin{tabular}{|c|c|c|c|c|c|c|c|}
\hline & (1) & $(2)$ & (3) & (4) & $(5)$ & (6) & (7) \\
\hline Manager incentives & $\begin{array}{l}-0.956 \\
(0.808)\end{array}$ & $\begin{array}{l}-0.821 \\
(0.812)\end{array}$ & $\begin{array}{l}-0.868 \\
(0.804)\end{array}$ & $\begin{array}{l}-1.012 \\
(0.826)\end{array}$ & $\begin{array}{l}-1.169 \\
(0.830)\end{array}$ & $\begin{array}{l}-1.021 \\
(0.853)\end{array}$ & $\begin{array}{l}-1.245 \\
(0.877)\end{array}$ \\
\hline Est. outperformance & $\begin{array}{c}2.723^{* * *} \\
(0.678)\end{array}$ & $\begin{array}{c}2.672^{* * *} \\
(0.675)\end{array}$ & $\begin{array}{c}2.849^{* * *} \\
(0.684)\end{array}$ & $\begin{array}{c}2.732^{* * *} \\
(0.680)\end{array}$ & $\begin{array}{c}2.877^{* * *} \\
(0.747)\end{array}$ & $\begin{array}{c}2.927^{* * *} \\
(0.763)\end{array}$ & $\begin{array}{c}3.007^{* * *} \\
(0.777)\end{array}$ \\
\hline Managerial risk-taking & $\begin{array}{c}-2.720^{* * *} \\
(0.803)\end{array}$ & $\begin{array}{c}-2.751^{* * *} \\
(0.797)\end{array}$ & $\begin{array}{c}-2.734^{* * *} \\
(0.800)\end{array}$ & $\begin{array}{c}-2.774^{* * *} \\
(0.821)\end{array}$ & $\begin{array}{c}-2.557^{* * *} \\
(0.843)\end{array}$ & $\begin{array}{c}-2.675^{\text {*** }} \\
(0.884)\end{array}$ & $\begin{array}{r}-2.852^{\text {*** }} \\
(0.895)\end{array}$ \\
\hline Loss aversion & $\begin{array}{c}2.106^{* * *} \\
(0.673)\end{array}$ & $\begin{array}{c}1.962^{* * *} \\
(0.684)\end{array}$ & $\begin{array}{c}2.143^{* * *} \\
(0.674)\end{array}$ & $\begin{array}{c}2.044^{* * *} \\
(0.699)\end{array}$ & $\begin{array}{c}1.914^{* * *} \\
(0.694)\end{array}$ & $\begin{array}{c}2.090^{* * *} \\
(0.717)\end{array}$ & $\begin{array}{c}1.678^{* *} \\
(0.750)\end{array}$ \\
\hline Fairness & $\begin{array}{l}-0.413 \\
(0.902)\end{array}$ & $\begin{array}{l}-0.321 \\
(0.901)\end{array}$ & $\begin{array}{c}-0.693 \\
(0.929)\end{array}$ & $\begin{array}{l}-0.337 \\
(0.932)\end{array}$ & $\begin{array}{l}-0.128 \\
(0.943)\end{array}$ & $\begin{array}{l}-0.452 \\
(0.955)\end{array}$ & $\begin{array}{l}-0.042 \\
(1.012)\end{array}$ \\
\hline Negative fairness & $\begin{array}{l}-0.554 \\
(0.559)\end{array}$ & $\begin{array}{l}-0.497 \\
(0.559)\end{array}$ & $\begin{array}{l}-0.546 \\
(0.556)\end{array}$ & $\begin{array}{l}-0.590 \\
(0.570)\end{array}$ & $\begin{array}{l}-0.668 \\
(0.571)\end{array}$ & $\begin{array}{l}-0.579 \\
(0.590)\end{array}$ & $\begin{array}{l}-0.696 \\
(0.601)\end{array}$ \\
\hline Est. Euro Stoxx level & $\begin{array}{c}0.006^{*} \\
(0.003)\end{array}$ & $\begin{array}{c}0.006^{*} \\
(0.003)\end{array}$ & $\begin{array}{c}0.006^{*} \\
(0.003)\end{array}$ & $\begin{array}{l}0.006^{*} \\
(0.003)\end{array}$ & $\begin{array}{l}0.007^{* *} \\
(0.003)\end{array}$ & $\begin{array}{c}0.007^{*} \\
(0.003)\end{array}$ & $\begin{array}{l}0.007^{* *} \\
(0.003)\end{array}$ \\
\hline Signalling & $\begin{array}{c}0.087 \\
(0.753)\end{array}$ & $\begin{array}{c}0.216 \\
(0.761)\end{array}$ & $\begin{array}{c}0.198 \\
(0.752)\end{array}$ & $\begin{array}{c}0.107 \\
(0.755)\end{array}$ & $\begin{array}{c}0.115 \\
(0.772)\end{array}$ & $\begin{array}{c}0.229 \\
(0.806)\end{array}$ & $\begin{array}{c}0.331 \\
(0.805)\end{array}$ \\
\hline Financial literacy & & $\begin{array}{c}1.337 \\
(1.296)\end{array}$ & & & & & $\begin{array}{c}0.964 \\
(1.563)\end{array}$ \\
\hline College & & & $\begin{array}{c}3.280 \\
(2.495)\end{array}$ & & & & $\begin{array}{c}3.832 \\
(2.789)\end{array}$ \\
\hline Income over 3000 EUR & & & & $\begin{array}{l}-0.754 \\
(2.357)\end{array}$ & & & $\begin{array}{l}-2.178 \\
(2.571)\end{array}$ \\
\hline Age & & & & & $\begin{array}{c}0.131 \\
(0.092)\end{array}$ & & $\begin{array}{c}0.152 \\
(0.096)\end{array}$ \\
\hline Male gender & & & & & & $\begin{array}{l}-1.537 \\
(4.456)\end{array}$ & $\begin{array}{c}-1.029 \\
(4.633)\end{array}$ \\
\hline Constant & $\begin{array}{c}8.552 \\
(10.012) \\
\end{array}$ & $\begin{array}{c}-4.973 \\
(16.468) \\
\end{array}$ & $\begin{array}{c}6.212 \\
(10.117) \\
\end{array}$ & $\begin{array}{c}9.482 \\
(10.417) \\
\end{array}$ & $\begin{array}{c}0.042 \\
(11.396) \\
\end{array}$ & $\begin{array}{c}8.746 \\
(11.425) \\
\end{array}$ & $\begin{array}{c}-9.606 \\
(18.498) \\
\end{array}$ \\
\hline Observations & 88 & 88 & 88 & 88 & 85 & 83 & 83 \\
\hline
\end{tabular}

This table reports Tobit regressions on maximum performance fee for the Text questions group of Study II. The results support the findings from the two-fund case of Study I. Estimated outperformance, managerial risk-taking and loss aversion are found to be significant predictors. However, asking for reasons first leads to a lower average level of the chosen performance fee which is reflected in the much lower constant in this group as compared to the Performance fee group. ${ }^{*}$ indicates significance at the $10 \%$-level, ${ }^{* *}$ at the $5 \%$-level, and ${ }^{* * *}$ at the $1 \%$-level. 
Table 9: Tobit model for Study II (Management fee group)

\begin{tabular}{|c|c|c|c|c|c|c|c|}
\hline & (1) & $(2)$ & $(3)$ & (4) & $(5)$ & (6) & (7) \\
\hline Manager incentives & $\begin{array}{c}0.209^{*} \\
(0.108)\end{array}$ & $\begin{array}{c}0.208^{*} \\
(0.110)\end{array}$ & $\begin{array}{c}0.207^{*} \\
(0.108)\end{array}$ & $\begin{array}{c}0.193^{*} \\
(0.108)\end{array}$ & $\begin{array}{c}0.212^{*} \\
(0.112)\end{array}$ & $\begin{array}{l}0.224^{* *} \\
(0.108)\end{array}$ & $\begin{array}{c}0.183 \\
(0.112)\end{array}$ \\
\hline Est. outperformance & $\begin{array}{c}-0.326^{* * *} \\
(0.116)\end{array}$ & $\begin{array}{c}-0.326^{* * *} \\
(0.117)\end{array}$ & $\begin{array}{c}-0.325^{* * *} \\
(0.116)\end{array}$ & $\begin{array}{c}-0.313^{* * *} \\
(0.116)\end{array}$ & $\begin{array}{c}-0.307^{* * *} \\
(0.114)\end{array}$ & $\begin{array}{c}-0.261^{* *} \\
(0.113)\end{array}$ & $\begin{array}{c}-0.264^{* *} \\
(0.113)\end{array}$ \\
\hline Managerial risk-taking & $\begin{array}{c}0.085 \\
(0.078)\end{array}$ & $\begin{array}{c}0.086 \\
(0.080)\end{array}$ & $\begin{array}{c}0.086 \\
(0.078)\end{array}$ & $\begin{array}{c}0.090 \\
(0.078)\end{array}$ & $\begin{array}{c}0.100 \\
(0.079)\end{array}$ & $\begin{array}{c}0.098 \\
(0.077)\end{array}$ & $\begin{array}{c}0.100 \\
(0.078)\end{array}$ \\
\hline Loss aversion & $\begin{array}{c}-0.286^{* * *} \\
(0.098)\end{array}$ & $\begin{array}{c}-0.284^{* * *} \\
(0.100)\end{array}$ & $\begin{array}{c}-0.287^{* * *} \\
(0.098)\end{array}$ & $\begin{array}{c}-0.292^{* * *} \\
(0.098)\end{array}$ & $\begin{array}{c}-0.268^{* * *} \\
(0.100)\end{array}$ & $\begin{array}{c}-0.195^{*} \\
(0.107)\end{array}$ & $\begin{array}{l}-0.205^{*} \\
(0.115)\end{array}$ \\
\hline Fairness & $\begin{array}{l}-0.050 \\
(0.110)\end{array}$ & $\begin{array}{l}-0.049 \\
(0.113)\end{array}$ & $\begin{array}{l}-0.052 \\
(0.111)\end{array}$ & $\begin{array}{l}-0.028 \\
(0.112)\end{array}$ & $\begin{array}{l}-0.077 \\
(0.111)\end{array}$ & $\begin{array}{l}-0.108 \\
(0.110)\end{array}$ & $\begin{array}{c}-0.083 \\
(0.114)\end{array}$ \\
\hline Negative fairness & $\begin{array}{c}-0.188^{* * *} \\
(0.068)\end{array}$ & $\begin{array}{c}-0.189^{* * *} \\
(0.069)\end{array}$ & $\begin{array}{c}-0.184^{* *} \\
(0.070)\end{array}$ & $\begin{array}{c}-0.187^{* * *} \\
(0.068)\end{array}$ & $\begin{array}{c}-0.180^{* * *} \\
(0.068)\end{array}$ & $\begin{array}{c}-0.200^{* * *} \\
(0.068)\end{array}$ & $\begin{array}{r}-0.197^{* * *} \\
(0.071)\end{array}$ \\
\hline Est. Euro Stoxx level & $\begin{array}{c}0.001^{* * *} \\
(0.000)\end{array}$ & $\begin{array}{c}0.001^{* * *} \\
(0.000)\end{array}$ & $\begin{array}{c}0.001^{* * *} \\
(0.000)\end{array}$ & $\begin{array}{c}0.001^{* * *} \\
(0.000)\end{array}$ & $\begin{array}{c}0.001^{* * *} \\
(0.000)\end{array}$ & $\begin{array}{c}0.001^{* * *} \\
(0.000)\end{array}$ & $\begin{array}{c}0.001^{\text {*** }} \\
(0.000)\end{array}$ \\
\hline Signalling & $\begin{array}{c}0.042 \\
(0.059)\end{array}$ & $\begin{array}{c}0.043 \\
(0.060)\end{array}$ & $\begin{array}{c}0.041 \\
(0.060)\end{array}$ & $\begin{array}{c}0.044 \\
(0.059)\end{array}$ & $\begin{array}{c}0.048 \\
(0.063)\end{array}$ & $\begin{array}{c}0.012 \\
(0.058)\end{array}$ & $\begin{array}{c}0.038 \\
(0.063)\end{array}$ \\
\hline Financial literacy & & $\begin{array}{c}0.033 \\
(0.116)\end{array}$ & & & & & $\begin{array}{c}0.104 \\
(0.116)\end{array}$ \\
\hline College & & & $\begin{array}{c}-0.048 \\
(0.222)\end{array}$ & & & & $\begin{array}{l}-0.029 \\
(0.227)\end{array}$ \\
\hline Income over 3000 EUR & & & & $\begin{array}{l}-0.189 \\
(0.194)\end{array}$ & & & $\begin{array}{l}-0.171 \\
(0.197)\end{array}$ \\
\hline Age & & & & & $\begin{array}{l}-0.008 \\
(0.008)\end{array}$ & & $\begin{array}{l}-0.005 \\
(0.008)\end{array}$ \\
\hline Male gender & & & & & & $\begin{array}{l}-0.193 \\
(0.352)\end{array}$ & $\begin{array}{l}-0.136 \\
(0.365)\end{array}$ \\
\hline Constant & $\begin{array}{l}-1.437 \\
(1.336)\end{array}$ & $\begin{array}{l}-1.739 \\
(1.688)\end{array}$ & $\begin{array}{l}-1.429 \\
(1.335)\end{array}$ & $\begin{array}{l}-1.407 \\
(1.328)\end{array}$ & $\begin{array}{l}-1.206 \\
(1.487)\end{array}$ & $\begin{array}{l}-1.431 \\
(1.375)\end{array}$ & $\begin{array}{l}-1.963 \\
(1.860)\end{array}$ \\
\hline Observations & 90 & 89 & 90 & 90 & 85 & 86 & 84 \\
\hline
\end{tabular}

This table reports Tobit regressions on maximum management fee for the Management fee group of Study II. Note that coefficients have to go in the opposite direction than in the previous tables in order to have the same implications as before. This is due to the fact that the management fee is the dependent variable now. As before, estimated outperformance and loss aversion are found to be significant predictors. With a focus on fixed fees, the fear of managerial risk-taking is not seen anymore. Fairness however becomes a more important issue. ${ }^{*}$ indicates significance at the $10 \%$-level, ${ }^{* *}$ at the $5 \%$-level, and ${ }^{* * *}$ at the $1 \%$-level. 